\title{
MicroRNA-34a: A Key Regulator in the Hallmarks of Renal Cell Carcinoma
}

\author{
Eman A. Toraih, ${ }^{1}$ Afaf T. Ibrahiem, ${ }^{2}$ Manal S. Fawzy, ${ }^{3,4}$ Mohammad H. Hussein, ${ }^{5}$ \\ Saeed Awad M. Al-Qahtani, ${ }^{6}$ and Aly A. M. Shaalan ${ }^{7,8}$ \\ ${ }^{1}$ Faculty of Medicine, Genetics Unit, Department of Histology and Cell Biology, Suez Canal University, P.O. 41522, Ismailia, Egypt \\ ${ }^{2}$ Faculty of Medicine, Department of Pathology, Mansoura University, Mansoura, Egypt \\ ${ }^{3}$ Faculty of Medicine, Department of Medical Biochemistry, Suez Canal University, P.O. 41522, Ismailia, Egypt \\ ${ }^{4}$ Faculty of Medicine, Department of Medical Biochemistry, Northern Border University, Arar, Saudi Arabia \\ ${ }^{5}$ Ministry of Health, Cairo, Egypt \\ ${ }^{6}$ Faculty of Medicine, Department of Physiology, Jazan University, Jazan, Saudi Arabia \\ ${ }^{7}$ Faculty of Medicine, Department of Histology and Cell Biology, Suez Canal University, Ismailia, Egypt \\ ${ }^{8}$ Faculty of Medicine, Department of Anatomy and Histology, Jazan University, Jazan, Saudi Arabia
}

Correspondence should be addressed to Eman A. Toraih; emantoraih@gmail.com

and Manal S. Fawzy; manal2_khashana@ymail.com

Received 29 April 2017; Revised 7 August 2017; Accepted 20 August 2017; Published 20 September 2017

Academic Editor: Simona G. Bungǎu

Copyright (c) 2017 Eman A. Toraih et al. This is an open access article distributed under the Creative Commons Attribution License, which permits unrestricted use, distribution, and reproduction in any medium, provided the original work is properly cited.

\begin{abstract}
Renal cell carcinoma (RCC) incidence has increased over the past two decades. Recent studies reported microRNAs as promising biomarkers for early cancer detection, accurate prognosis, and molecular targets for future treatment. This study aimed to evaluate the expression levels of miR-34a and 11 of its bioinformatically selected target genes and proteins to test their potential dysregulation in RCC. Quantitative real-time PCR for miR-34a and its targets; MET oncogene; gene-regulating apoptosis (TP53INP2 and DFFA); cell proliferation (E2F3); and cell differentiation (SOX2 and TGFB3) as well as immunohistochemical assay for VEGFA, TP53, Bcl2, TGFB1, and Ki67 protein expression have been performed in 85 FFPE RCC tumor specimens. Clinicopathological parameter correlation and in silico network analysis have also implicated. We found RCC tissues displayed significantly higher miR-34a expression level than their corresponding noncancerous tissues, particularly in chromophobic subtype. MET and E2F3 were significantly upregulated, while TP53INP2 and SOX2 were downregulated. ROC analysis showed high diagnostic performance of miR-34a $(\mathrm{AUC}=0.854), M E T$ (AUC=0.765), and E2F3 (AUC=0.761). The advanced pathological grade was associated with strong TGFB1, VEGFA, and Ki67 protein expression and absent Tp53 staining. These findings indicate miR-34a along with its putative target genes could play a role in RCC tumorigenesis and progression.
\end{abstract}

\section{Introduction}

Renal cell carcinoma (RCC) accounts for approximately $3 \%$ of human malignancies, and its incidence appears to be increasing globally [1]. RCC is not a single disease; although it is derived from cells of the renal tubular epithelium, it has several histological subtypes which differ in their clinical outcome and biological features. It is classified into clear cell RCC accounting for (75\%) of cases, papillary RCC (10$15 \%)$, chromophobe RCC (5\%), collecting duct RCC $(<1 \%)$, and unclassified subtype [2]. For the refinement of RCC therapeutic strategies, a better realization of the RCC-underlying molecular mechanisms will be mandatory [3].

Over the past few years, emerging numerous bioinformatic tools have been developed to identify candidate disease-causing genes [4], including microRNA (miRNA) genes. This class of noncoding RNAs is small, single stranded, and 19-25 nucleotide long that act as negative regulators involved in posttranscriptional silencing of the gene expression [5]. An aberrant miRNA expression could 
contribute to cancer development and progression $[6,7]$ and could affect their target genes that are involved in many biological processes, such as cell differentiation, proliferation, apoptosis, metabolism, and development [8]. Recently, the potential therapeutic use of miRNAs has been evaluated due to their dynamic and reversible properties. This may include oncomir (oncogenic miRNA) inhibition, or tumor suppressor-miRNA replacement therapies $[6,9]$.

MicroRNA-34a gene (MIR-34A) that is located on chromosome $1 \mathrm{p} 36$ belongs to one of evolutionary-conserved miRNA families (MIR-34 family) that consists of three members: MIR-34A, MIR-34B, and MIR-34C [10]. MIR-34A has its own transcript and is expressed at higher levels than MIR$34 \mathrm{~B} / \mathrm{C}$ in most tissues, and this expression could be dysregulated in multiple diseases, especially in cancers [11]. It is involved in p53 pathways and is implicated in cell death/survival signaling, the cell cycle, and differentiation, thereby playing a regulatory role in carcinogenesis [12]. Previous studies have reported that several key molecules were identified as targets of miR-34a, including Bcl-2 (B-cell lymphoma 2) [13], TGFB (transforming growth factor-beta) [14], the transcription inducer of cell cycle progression E2F3a [15], $M E T$ oncogene [16, 17], and vascular endothelial growth factor (VEGF) [18]. In addition, our bioinformatic analysis that has been discussed in details in Materials and Methods section of the current work has revealed other miRNA-34apredicted target genes that could be involved in cancerrelated biology, including genes for apoptosis [TP53INP (tumor protein p53 inducible nuclear protein), Tp53, and DFFA (DNA fragmentation factor subunit alpha)], cell proliferation (Ki67), and cell differentiation SOX2 (sex-determining region Y-box 2). As miR-34a has many different targets in regulating different kinds of human cancer, $\mathrm{Yu}$ et al. [18] suggested the role of miR-34a is possibly tumor-specific and highly dependent on its targets in different cancer cells.

Whether miR-34a or any one of its selected aforementioned 11 putative target genes or proteins could be related to RCC pathogenesis and/or progression in our population still lacks of solid evidence. Therefore, we aimed to investigate the expression level of miR-34a and a panel of selected putative targets in an attempt to better understand the molecular mechanisms that underlie the tumorigenesis and progression of RCC. This could represent potential future therapeutic targets in renal cell carcinoma.

\section{Materials and Methods}

2.1. Study Population. Eighty-five archived formalin-fixed paraffin-embedded (FFPE) renal samples that have been taken from patients who underwent radical nephrectomy for a primary RCC and dating back for 3 years were collected from Pathology laboratory of Mansoura Oncology Center, Mansoura and Pathology laboratory of the Suez Canal University Hospital, Ismailia, Egypt. None of the patients received any neoadjuvant chemotherapy or radiotherapy. Complete clinicopathological data, including (patients' age, sex, and tumor's site and size), were obtained from patient medical records. Sections of cancer-free tissues adjacent to the tumor were cut, examined, and collected to serve as controls during the genetic profiling. Samples that were not homogeneous, histologically well-characterized primary renal cancer, nor had cancer-free adjacent tissues determined by an experienced pathologist have been excluded. The study was conducted in accordance with the guidelines in the Declaration of Helsinki and approved by the Medical Research Ethics Committee of Faculty of Medicine, Suez Canal University. Written informed consent was obtained from all participants before providing the archived tissue samples as part of their routine register in our University Teaching Hospitals.

2.2. Bioinformatic Selection of miRNA-34a and the Study Molecular Targets. Predicted and experimentally validated miRNAs that significantly target renal cell carcinoma KEGG pathway (hsa05211) were identified by DIANA-mirPath v3.0 web server via Reverse Search module and TarBase v7.0 pipeline [19]. The most top and highly significant miRNA involved in this pathway was hsa-miR-34a-5p $(p=1.275767$ $e-88$ ) with 28 target genes, including $M E T$ oncogene and three angiogenesis-related genes (VEGFA, TGFB1, TGFB3). Assessment of miR-34a regulatory roles in cancer biology was performed by DIANA-mirPath v3.0 online software (Figure 1).

The list of all experimentally validated target genes for miR-34a-5p was retrieved from miRTarBase v20 (http:// mirtarbase.mbc.nctu.edu.tw/) [20] and DIANA-TarBase v7.0 (http://diana.imis.athena-innovation.gr/) [21]. A panel of other targets involved in cancer-related biology was chosen. It included genes for apoptosis (Tp53, TP53INP2, and $D F F A)$, antiapoptosis (BCL2), cell proliferation (E2F3 and Ki67), and cell differentiation (SOX2) (Figure 2). Structural analysis of MIR-34A gene and transcripts were retrieved from http://Ensembl.org. Gene expression of MIR-34A across normal human tissues was obtained from http://BioGPS.org and Expression Atlas. Complementary base pairing of miR-34a-5p seed region with the selected mRNA targets was confirmed by both http://microRNA.org resource [22] and miRTarBase v20. Prior publications demonstrating functional experimental validation of miRNA-target interactions by different methods (as luciferase reporter assay, western blot, microarray, qRT-PCR, and immunocytochemistry) are listed in Supplementary Table S1 available online at https://doi.org/10.1155/2017/3269379. A functional interaction network of selected target proteins was implemented using STRING v10 program (http://string-db.org), inferring protein-protein associations from coexpression data [23].

2.3. MicroRNA-34a and Gene Expression Analysis. Total RNA, including the small RNAs, was isolated from FFPE tissue sections (5 to $8 \mu \mathrm{m}$ thick) using miRNeasy FFPE Kit (Qiagen, 217504) following the protocol supplied by the manufacturer. Briefly, after the removal of paraffin by xylene and washing the sample with ethanol several times, proteins were degraded by incubation with proteinase $\mathrm{K}$ solution at $45^{\circ} \mathrm{C}$ for a few hours and later incubation with DNAses for DNA digestion. Total RNA quantity and quality were measured by Nanodrop ND-1000 (NanoDrop Technologies, Wilmington, DE). Samples with a $260 / 280 \mathrm{~nm}$ absorbance 

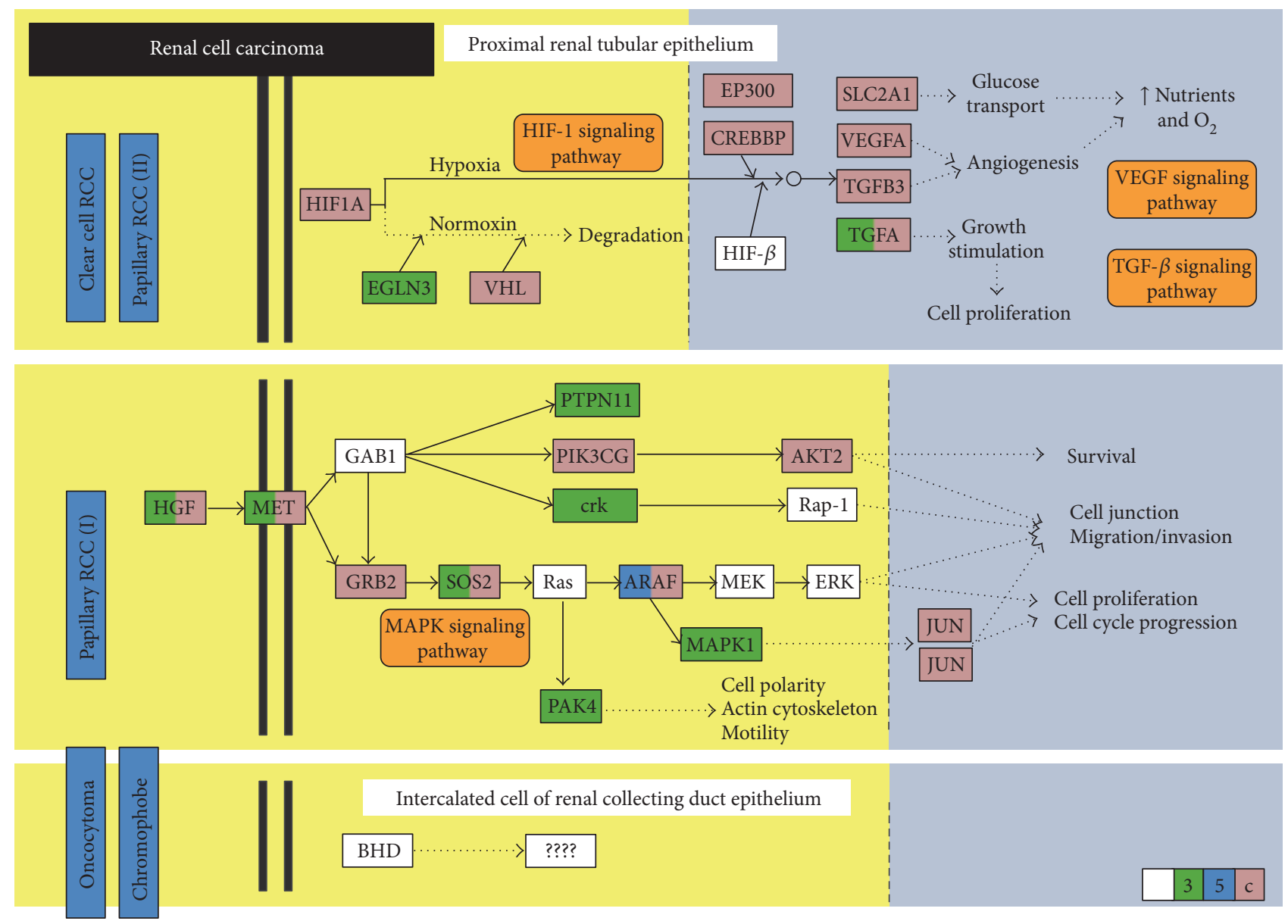

FIGURE 1: Predicted target genes of miRNA-34a in renal cell carcinoma pathway [KEGG hsa05211]. Disease pathways for each pathological subtype are shown. Hsa-miR-34a-5p can target several genes in RCC pathway. They have complementary regions at their $3^{\prime} U T R, 5^{\prime} U T R$, or coding sequence (CDS): HIF-1, VEGF, and TGF- $\beta$ signaling pathways in clear cell and papillary type II RCC (eosinophilic), as well as MAPK signaling pathway in papillary RCC type I (basophilic). However, candidate genes and the role of miR-34a in oncocytoma and chromophobic RCC pathways are still undetermined. Colored box: miRNA-34a target gene; green color: target on $3^{\prime} \mathrm{UTR}$ sequence; blue color: target on $5^{\prime}$ UTR sequence; pink color: target on CDS; white box: not predicted target.

ratio less than 1.8 were discarded, and new sections of the corresponding tissue block were cut and purified, if possible. Subsequent reverse transcription (RT) and amplification of cDNA by real-time PCR using StepOne ${ }^{\mathrm{TM}}$ Real-Time PCR System (Applied Biosystems) were done as described in details previously $[8,24]$. As the quantitation cycle $(\mathrm{Cq})$ values of RNU6B small RNA and GAPDH were uniformly and stably expressed with no significant difference between cancer and noncancer tissues, they have been run for normalization of miRNA-34a and target gene mRNA expression analysis, respectively. All the PCR reactions were carried out in accordance with the Minimum Information for Publication of Quantitative Real-Time PCR Experiments guidelines [25]. Ten percent randomly selected study samples were reevaluated in separate runs for the study gene expressions to test the reproducibility of the qPCR which showed very close $\mathrm{Cq}$ value results and low standard deviations.

2.4. Histopathological Examination. Sections of $4 \mu \mathrm{m}$ thickness have been cut from FFPE blocks of RCC tissues for routine $H \& E$ examination, and other sections were prepared on charged slides for immunohistochemistry. Examination of three tumor slides from each specimen was done with an Olympus CX31 light microscope. Photos were obtained by a PC-driven digital camera (Olympus E-620). Cases were reviewed to determine the histological type according to the International Society of Urological Pathology (ISUP) Vancouver Modification of WHO (2004) Histologic Classification of Kidney Tumors [26]. Nuclear grade is assessed according to Fuhrman et al. [27]. Tumors were staged according to the International Union Against Cancer [28].

2.5. Immunohistochemistry Examination and Analysis. Immunohistochemical analysis for $\mathrm{p} 53$ protein, $\mathrm{Bcl} 2$ protein, Ki67, TGFb, and VEGF with a labelled streptavidin-biotinperoxidase complex technique was performed on tumor sections. The primary antibodies were mouse monoclonal antibodies against p53 (clone BP-53-12, monoclonal mouse anti-human p53, c-Kit, Genemed, California, USA, diluted 1:50), Bcl2 (code 226M98, monoclonal mouse anti-human 


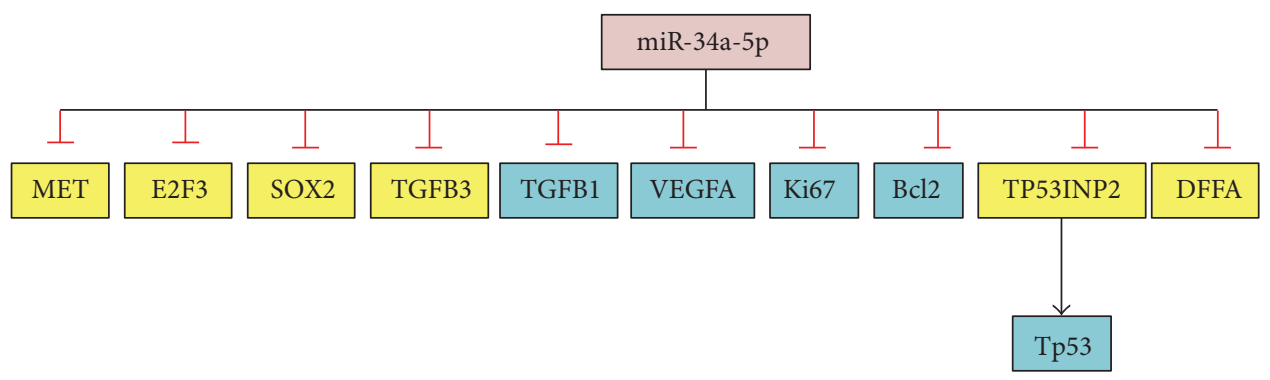

(a)

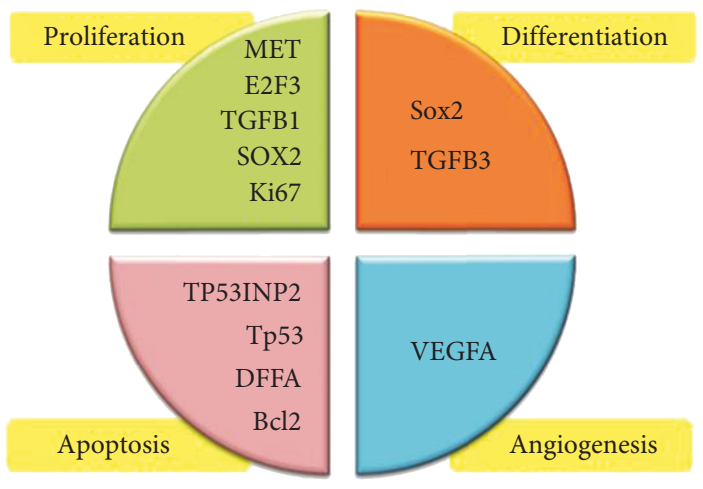

(b)

FIGURE 2: miR-34a target genes regulating the hallmarks of cancer. Eleven targets were investigated in the study. (a) List of targets analyzed by either immunohistochemistry (blue box) or quantitative real-time PCR (yellow box). (b) Classification of the miR-34a target genes and proteins according to their major role in cancer-related biology. They are enrolled in cellular differentiation, proliferation, apoptosis, and angiogenesis.

Bcl2, cell marque, prediluted), Ki67 (code number 1633, monoclonal mouse anti-human MIB1, DAKO corporation Carpinteria CA, USA, prediluted), TFGFB (ab9248, monoclonal mouse anti-TFGFB, abcam, USA, diluted 1:50), and VEGF (clone, GTX102643, monoclonal mouse anti-VEGFA, GeneTex, USA, diluted 1:50). A high sensitive kit has been used as a detection kit (DakoCytomation EnVision and dual link system peroxidase code K4061) using DAB as a chromogene. Antigen retrieval required pretreatment with $1 \mathrm{mM}$ EDTA (at $\mathrm{pH}$ 8.0) for 20 minutes (p53, Bcl2, and VEGF) and 60 minutes (Ki67, and TGFb) in microwave oven. Proper positive and negative controls were performed. As a positive control, breast carcinoma has been run for p53, tonsils for $\mathrm{Ki67}$, lymph node for $\mathrm{Bcl} 2$, and cells of proximal and distal convoluted tubules of nearby tumor-free kidney for TGFb. In addition, placental tissue was stained for VEGF as a positive control for VEGF antibody. As a negative control, sections were stained without the addition of a primary antibody.

For the immunohistochemistry assessment, examination of all prepared slides from each specimen was done with an Olympus CX31 light microscope. Photos were obtained from a PC-driven digital camera (Olympus E-620) and analyzed by Olympus Soft Imaging. Slides were scanned by $\times 40$ magnification. Ten cellular areas were selected (i.e., the so-called hot spots) and evaluated at $\times 400$ magnification. Positive p53 protein staining was defined as nuclear staining, and cytoplasmic staining was considered nonspecific and ignored. The percentage of tumor cell nuclei with positive staining was evaluated in relation to the total number of neoplastic nuclei in at least 10 fields observed at magnification $\times 400$. Scoring of immunostained was categorized as mentioned in previous literature as follows: $3+=$ high level $(91-100 \%$ of positive cells), $2+=$ medium level (11-90\% of positive cells), $1+=$ low level (up to $10 \%$ of positive cells), $-=$ negative cells ( $0 \%$ of positive cells) [29].

$\mathrm{Ki}-67$ antigen labeling was localized to the nucleus with a fine, strong, and homogenous brown granularity. Staining was considered positive if any nuclear staining was seen. Ki67 labeling index was done by calculating the ratio of positive nuclei in relation to the total number of neoplastic nuclei in 10 HPFs. Ki67 was considered to be abnormal when $>10 \%$ tissue positivity was observed. The labeling index (number of positive tumor cells/total number of tumor cells expressed as a percentage) was calculated in every specimen. The Ki67 proliferation index was considered low if $0-30 \%$ of tumor cells was positive, moderate PI if 31-69\% was positive, and high if $\geq 70 \%$ was positive. Unequivocal nuclear reactivity was considered positive [30, 31].

The BCL2 positivity was determined by cytoplasmic staining (brown) of neoplastic cells which are deep colored. The percentage of positive cells at the whole section after exclusion of the areas of reactive $\mathrm{T}$ cells was determined. It was scored negative if $5 \%$ or less of neoplastic cells was stained. The value of BCL2 was considered weak positive if $6 \%$ to less than $50 \%$ was brown stained, and strong positive if $\geq 50 \%$ of tumor cells was brown stained [32].

TGFB immunohistochemistry specimens were classified based on the intensity of staining as follows: weak or absent staining ( $<10 \%$ of cells), intermediate (10-25\%), focally 
strong (25-50\%), and strong (> 50\% of cells) [33]. VEGF sections were considered positive for VEGF if the membranes or cytoplasm of more than $10 \%$ of tumor cells was stained [34].

2.6. Statistical Analysis. Data were managed using the $\mathrm{R}$ package (version 3.3.2). Categorical variables were compared using the chi-square $\left(\chi^{2}\right)$ or Fisher's exact tests where appropriate, while Mann-Whitney $U$ (MW) and Kruskal-Wallis (KW) tests were used to compare continuous variables. The correlation between miR-34a level and mRNAs and protein expression was calculated by Spearman's rank correlation analysis. A two-tailed $p$ value of $<0.05$ was considered statistically significant. The receiver operating characteristic (ROC) curves were performed to get the best cutoff values of either miR-34a or mRNAs for discriminating RCC from noncancer tissues. The fold change of miRNA and mRNA expressions in each patient cancer tissue relative to the corresponding cancer-free tissue was calculated via Livak method based on the quantitative cycle $(\mathrm{Cq})$ values with the following equation: relative quantity $=2^{-\Delta \Delta \mathrm{Cq}}$, where $\Delta \Delta \mathrm{C}_{\mathrm{q}}=\left(\mathrm{C}_{\mathrm{q}} \text { miRNA-C } \mathrm{q} \text { NB6 }\right)_{\mathrm{RCC}}-\left(\mathrm{C}_{\mathrm{q}}\right.$ miRNA-C $\mathrm{C}_{\mathrm{q}}$ NBU6 $)_{\text {NAT }}$ in case of miR-34a analysis and where $\Delta \Delta \mathrm{C}_{\mathrm{q}}=$ $\left(\mathrm{C}_{\mathrm{q}} \text { mRNA-C } \mathrm{qAPDH}\right)_{\mathrm{RCC}}-\left(\mathrm{C}_{\mathrm{q}} \text { mRNA-C }_{\mathrm{q}} \mathrm{GAPDH}\right)_{\mathrm{NAT}}$ in case of study gene target analysis [35].

\section{Results}

3.1. Baseline Characteristics of the Study Population. In the current study, 85 patients (32 females and 53 males) were enrolled in the study. Their age ranged from 20 to 79 years old with mean \pm SD of $52.23 \pm 11.12$. Renal cancer samples were compared to normal tissues. There was no significant difference in age and gender between FFPE tumor samples and normal renal tissues ( $p=0.087$ and $p=0.214$, resp.). The clinicopathological characteristics of renal cell carcinoma patients are demonstrated in Table 1. According to the 2004 WHO classification, several histological RCC subtypes were recognized in the study population. The most frequent histological subtypes included clear cell renal cell carcinomas (ccRCC), papillary renal cell carcinomas (pRCC), and chromophobe renal cell carcinomas (crRCC). Most cancer specimens were moderately or poorly differentiated; nevertheless, low proportions of tumors had high tumor size (T3), positive lymph node involvement, capsular and pelvic infiltration, and vascular invasion.

3.2. Gene and Protein Expression Analysis. Using qRT-PCR technology and immunohistochemistry, gene and protein expression analyses were used to identify differential molecular changes between tumor and normal renal tissues. Gene expression profiling revealed a significant overexpression of miR-34a in almost all RCC patients (91.7\%) with an overall median and quartile values of 7.97 (2.37-29.54). In addition, among the 6 genes that have been predicted to be targeted by miR-34a via the in silico computational tools, two genes were significantly upregulated (MET and E2F3) in $87.1 \%$ of FFPE samples, while two others were downregulated (TP53INP2 and SOX2) in almost all RCC patients compared to noncancer tissues (Figure 3). However, correlation analysis revealed
TABLE 1: Clinicopathological characteristics of renal cell carcinoma patients $(n=85)$.

\begin{tabular}{|c|c|c|}
\hline Variables & $N$ & $\%$ \\
\hline \multicolumn{3}{|l|}{ Age } \\
\hline $20 y$ & 5 & 5.9 \\
\hline $40 \mathrm{y}$ & 47 & 55.3 \\
\hline $60 y$ & 33 & 38.8 \\
\hline \multicolumn{3}{|l|}{ Gender } \\
\hline Females & 34 & 40.0 \\
\hline Males & 51 & 60.0 \\
\hline \multicolumn{3}{|l|}{ Affected side } \\
\hline Right & 47 & 44.7 \\
\hline Left & 38 & 55.3 \\
\hline \multicolumn{3}{|l|}{ Histological type } \\
\hline Clear cell RCC & 47 & 55.3 \\
\hline Papillary RCC & 15 & 17.6 \\
\hline Chromophobic RCC & 13 & 15.3 \\
\hline Unclassified & 10 & 11.8 \\
\hline \multicolumn{3}{|l|}{ Pathological grade } \\
\hline Grade 1 & 11 & 12.9 \\
\hline Grade 2 & 51 & 60.0 \\
\hline Grade 3 & 23 & 27.1 \\
\hline \multicolumn{3}{|l|}{ Tumor size } \\
\hline $\mathrm{T} 1$ & 25 & 29.4 \\
\hline $\mathrm{T} 2$ & 42 & 49.4 \\
\hline T3 & 18 & 21.2 \\
\hline \multicolumn{3}{|l|}{ LN involvement } \\
\hline Negative & 77 & 90.6 \\
\hline Positive & 8 & 9.4 \\
\hline \multicolumn{3}{|l|}{ Capsular infiltration } \\
\hline Negative & 60 & 70.6 \\
\hline Positive & 25 & 29.4 \\
\hline \multicolumn{3}{|l|}{ Vascular infiltration } \\
\hline Negative & 71 & 83.5 \\
\hline Positive & 14 & 16.5 \\
\hline \multicolumn{3}{|l|}{ Renal pelvis infiltration } \\
\hline Negative & 79 & 92.9 \\
\hline Positive & 6 & 7.1 \\
\hline
\end{tabular}

Data are presented as $N$ (number) and \% (percentage); RCC: renal cell carcinoma; T: tumor size; LN: lymph node.

no significant relationship of miR-34a with the tested target genes (Supplementary Table S2 and Figure S1).

Immunohistochemistry of renal tissue samples demonstrated variable staining patterns (Figure 4). Ki-67 expression, a cell proliferation marker, was detected in all cases of RCC but with variable level of expression. Low level of expression $(<10 \%)$ was detected in 28 cases $(70 \%)$, while high expression ( $\geq 10 \%)$ was noted in 12 cases $(30 \%)$. Similarly, the angiogenesis-mediated protein (VEGFA) and the antiapoptotic marker $(\mathrm{Bcl} 2)$ were expressed in all cancer tissues. Eighty percent of patients had high expression of VEGFA, while only $20 \%$ demonstrated weak staining. Antihuman 


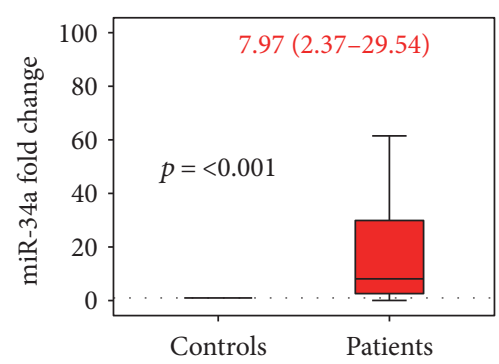

(a)

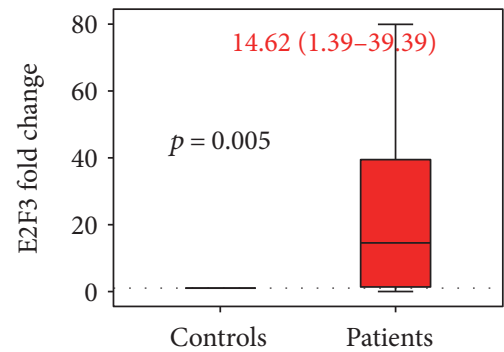

(c)

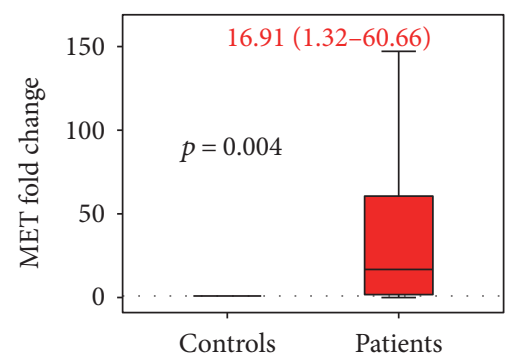

(b)

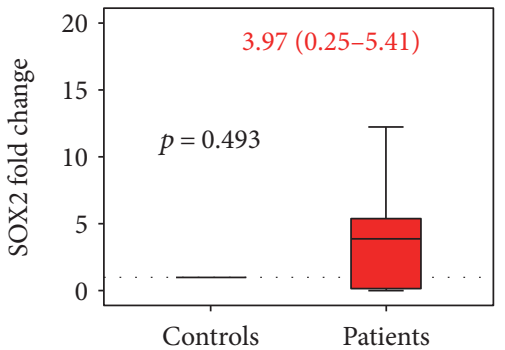

(d)

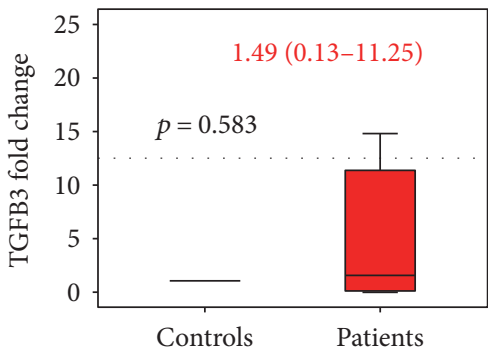

(e)

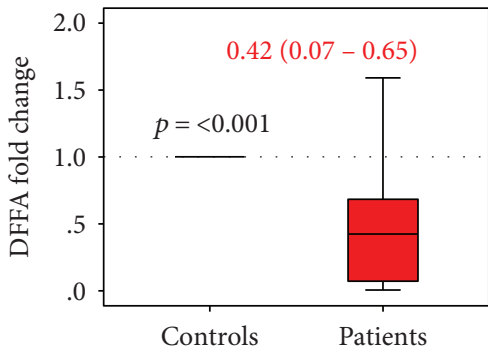

(f)

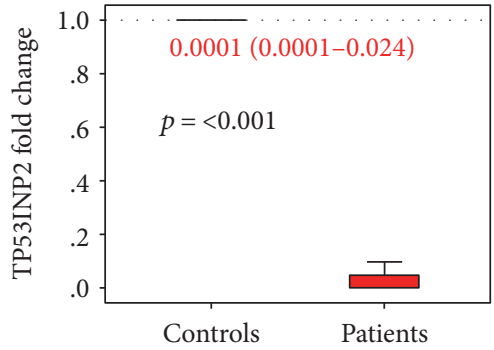

(g)

FIgURE 3: Gene expression profiling in cancer and normal renal tissues. Data are represented as medians. The box defines upper and lower quartiles (25\% and 75\%, resp.), and the error bars indicate upper and lower adjacent limits. Expression levels of miR-34a and targets in cancer and normal tissues were normalized to RNU6B and GAPDH, respectively. Fold change was calculated using the delta-delta CT method $\left(2^{-\Delta \Delta C T}\right)$ in comparison to normal renal tissues. The gray dash line represents the expression level of normal renal tissues (equivalent to 1.0). $p$ values $<0.05$ were considered statistical significant. Mann-Whitney $U$ test was used for comparison. Median and quartile values of patients are noted in red.

$\mathrm{Bcl} 2$ antibody was widely distributed all over the renal cancer tissues. Strong expression was noted in $75 \%$ of samples. For TGFB1 protein, most of cancer tissue attained moderate to strong expression in the cytoplasm, but the protein was less intense in approximately one-fifth of patients and absent in three samples only. In contrast, expression of the tumor suppressor protein (Tp53) was not detected by immunohistochemistry in less than half of tumor specimens. Unlike tumor cells, which had nuclear staining, lining cells of the proximal tubules stained the cytoplasm only.

ROC curve analysis of all genes and proteins showed significant high diagnostic performance of miR-34a $(\mathrm{AUC}=0.854), \operatorname{MET}(\mathrm{AUC}=0.765)$, and E2F3 (AUC= $0.761)$ in differentiating between cancer specimens and noncancer tissues (Table 2).

3.3. Association of Gene and Protein Signature with Clinicopathological Features. The expression of miR-34a was markedly higher in RCC samples with chromophobic renal cell carcinoma and lower in clear cell type $(p=0.039)$
(Figure 5(a)). In addition, its level was inversely correlated with the tumor pathological grade $(r=-0.301, p=0.037)$. Among the target genes, lower levels of three genes E2F3, $S O X 2$, and DFFA were significantly associated with capsular, pelvic, and vascular invasion, respectively (Figures 5(b), 5(c), and $5(\mathrm{~d})$ ). These findings were consistent with Spearman's correlation analysis (Supplementary Table S3).

Immunohistochemistry photos of the target proteins in renal tissues in relation with pathological parameters are illustrated in Figure 6. The advanced pathological grade was significantly associated with strong expression of Ki67 $(p=0.001)$, TGFB1 $(p=0.034)$, VEGFA proteins $(p=0.001)$, and absent Tp53 staining ( $p=0.029)$ (Figures 7(a), 7(b), 7(c), and $7(d))$. Larger tumor size and capsular infiltration also showed higher Ki67 expression $(p=0.027$ and $\mathrm{p}=0.014$, resp.) (Figures $7(\mathrm{e})$ and $7(\mathrm{f})$ ). Additionally, there was differential expression of TGFB1 and Tp53 proteins according to the specimen histopathological diagnosis, with stronger staining in chromophobic renal cell carcinoma type (Figures $7(\mathrm{~g})$ and $7(\mathrm{~h})$ ). Similarly, correlation analysis 


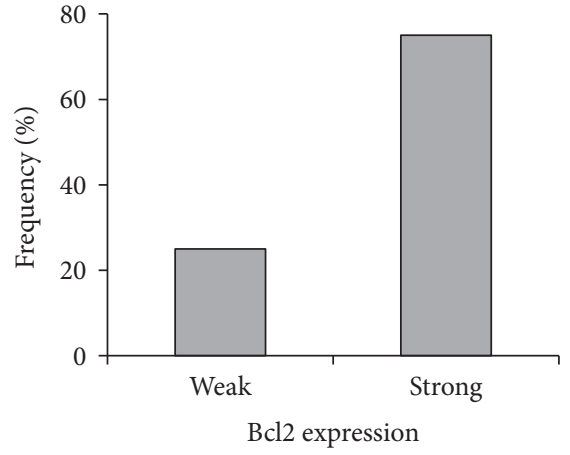

(a)

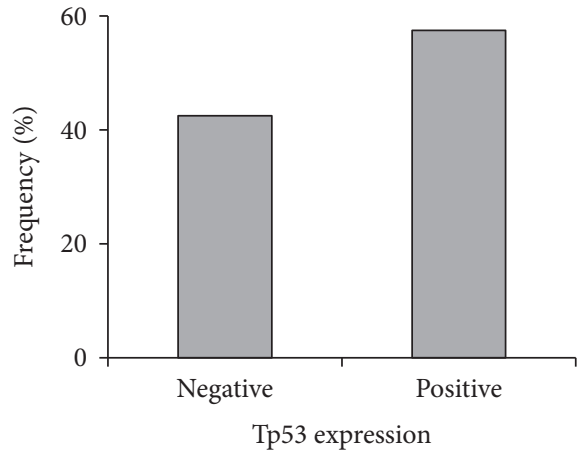

(b)

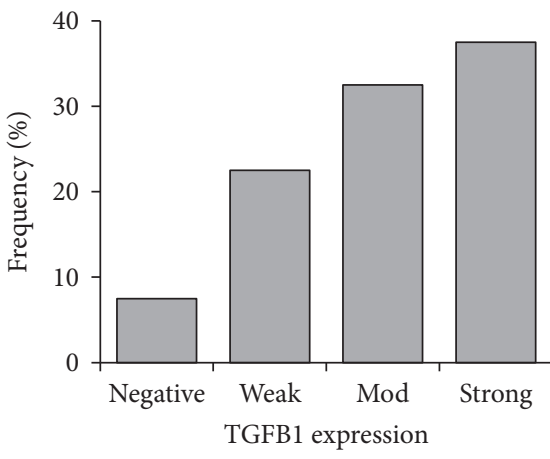

(c)

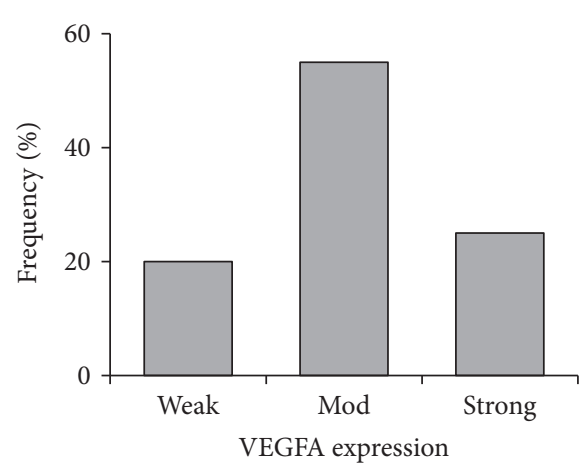

(d)

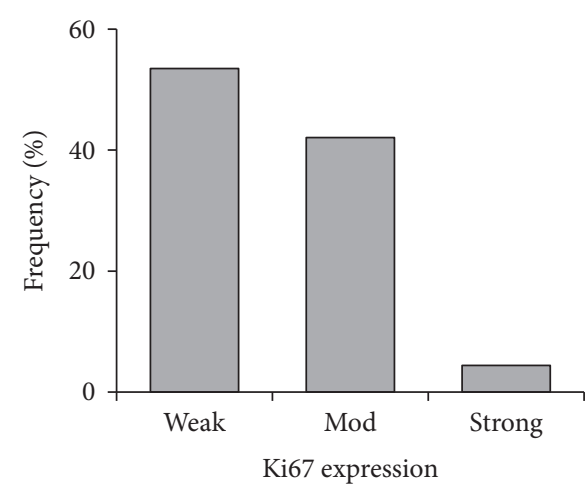

(e)

FIGURE 4: Frequency of Immunohistochemistry markers of miR-34a putative target proteins in RCC specimens. Five protein markers were examined, Bcl2, Tp53, TGFB1, VEGFA, and Ki67.

TABLE 2: ROC curve of miRNA-34a and target genes in renal cancer and normal tissues.

\begin{tabular}{|c|c|c|c|c|c|}
\hline \multirow{2}{*}{ Variable(s) } & \multirow{2}{*}{ Area } & \multirow{2}{*}{ Standard error } & \multirow{2}{*}{$p$ value } & \multicolumn{2}{|c|}{$95 \%$ confidence interval } \\
\hline & & & & Lower bound & Upper bound \\
\hline miR-34a & 0.854 & 0.051 & $<0.001$ & 0.754 & 0.954 \\
\hline MET & 0.765 & 0.059 & 0.005 & 0.648 & 0.881 \\
\hline E2F3 & 0.761 & 0.063 & 0.006 & 0.638 & 0.884 \\
\hline SOX2 & 0.571 & 0.094 & 0.479 & 0.388 & 0.755 \\
\hline TGFB3 & 0.553 & 0.081 & 0.586 & 0.395 & 0.711 \\
\hline DFFA & 0.118 & 0.053 & 0.068 & 0.014 & 0.222 \\
\hline TP53INP2 & 0.587 & 0.062 & 0.173 & 0.466 & 0.709 \\
\hline Combined first three markers & 0.793 & 0.034 & $<0.001$ & 0.727 & 0.859 \\
\hline All combined markers & 0.589 & 0.030 & 0.014 & 0.530 & 0.648 \\
\hline
\end{tabular}

Bold values are statistically significant at $p<0.05$.

between proteins and clinicopathological characteristics demonstrated moderate correlation of Ki67 with histopathological diagnosis $(r=-0.419, p=0.007)$, grade $(r=0.690$, $p<0.001)$, tumor size $(r=0.389, p \leq 0.001)$, LN invasion $(r=0.351, p=0.026)$, and capsular infiltration $(r=0.431$, $p=0.006)$. TGFB1 protein showed moderate correlation with histopathological diagnosis $(r=0.427, p=0.006)$ and tumor grade $(r=0.441, p=0.004)$. VEGFA protein also showed a significant positive correlation with pathological grade $(r=0.563, p<0.001)$. In contrast, there was a negative correlation between Tp53 and grade $(r=-0.403, p=0.010)$ (Supplementary Table S3).

3.4. In Silico Data Analysis. Hsa-miR-34a is encoded by MIR-34A gene (ENSG00000284357), mapped at 1p36.22. The gene has a single exon which contains a p53-binding site within a $\mathrm{CpG}$ island about $30 \mathrm{~kb}$ upstream of the mature MIR-34A sequence and encodes for a transcript of $110 \mathrm{bp}$ in length. The precursor miRNA stem-loop is processed in the cytoplasm of the cell, with the predominant miR-34a 


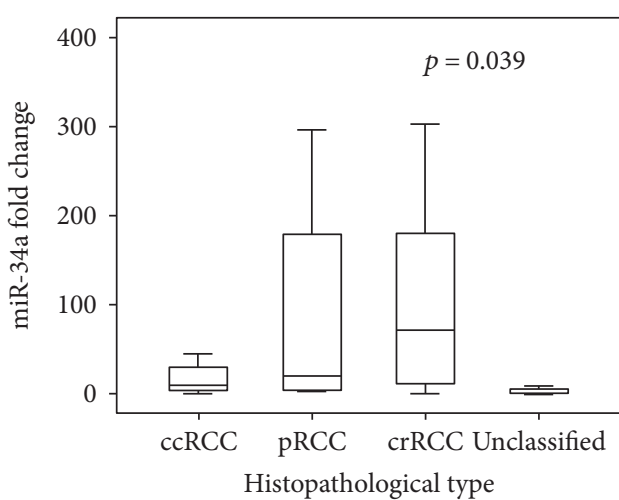

(a)

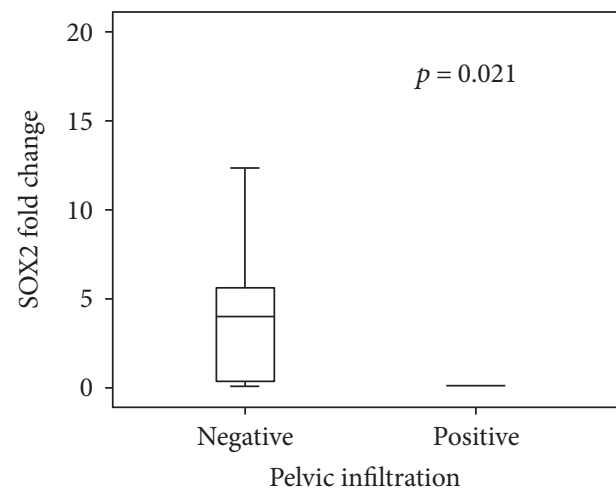

(c)

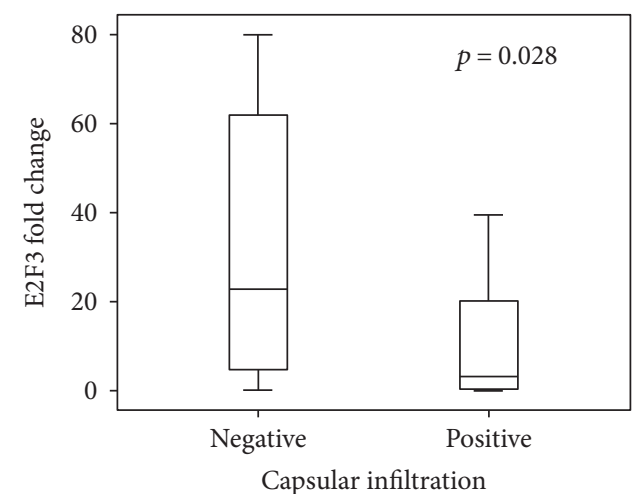

(b)

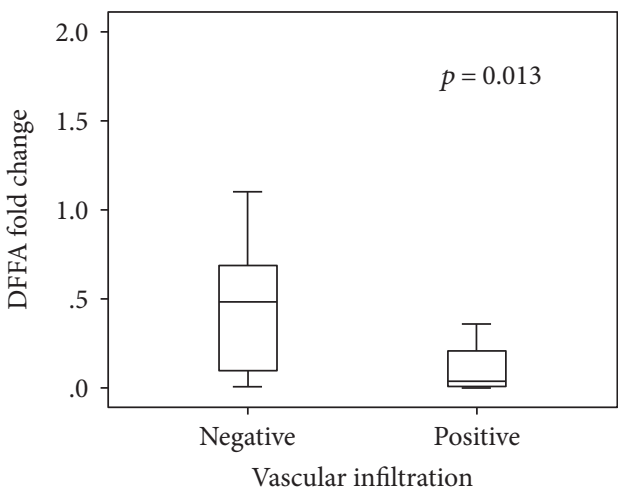

(d)

Figure 5: Association of miR-34a and target genes with the clinicopathological features in RCC patients. (a) Higher expression of miR-34a was significantly associated with chromophobic RCC subtype. (b) Lower levels of E2F3 were associated with capsular infiltration. (c) Lower levels of SOX2 had higher frequency of pelvic infiltration in RCC tumor tissues. (d) DFFA downregulation was associated with vascular infiltration.

mature sequence excised from the $5^{\prime}$ arm of the hairpin. Secondary structure of hsa-miR-34a stem-loop predicted by computational programs is illustrated in Figure 8(a). Functional characterization of miR-34a based on differential expression experiments revealed its control on numerous cancer-related molecular pathways and cellular processes. It can control up to 115 genes involved in pathways in cancer (hsa05200), in addition to dozens of genes in particular tumor types (Figure 8(b)). As shown in the heat map, the most top five significant pathways targeted by miR-34a were microRNAs in cancer, fatty acid biosynthesis, proteoglycans in cancer, adherence junction, and cell cycle (Figure 8(b) and Supplementary Table S4).

Interaction of mature miR-34a-5p with complementary sites of selected experimentally validated targets is shown in Supplementary Figure S2. Protein-protein interaction between the targets is shown in Supplementary Figure S3. Enrichment analysis of the target panel elucidated their functional impact on numerous biological processes and cancer KEGG pathways (Supplementary Table S5 and S6).

\section{Discussion}

A key goal in clinical oncology is the development of therapeutic strategies that impede specific deregulated biological pathways in cancer. Understanding these pathways which involve candidate disease-causing genes will provide new therapeutic modalities for renal cancer.

In the current study, upregulation of miR-34a was observed in more than $90 \%$ of RCC patients, with median fold change of 7.97 in RCC FFPE tissues compared to noncancer tissues. ROC analysis revealed a high diagnostic performance of miR-34a in discriminating between cancer and noncancer tissues. However, higher levels showed a better prognosis (i.e., it was moderately correlated with well differentiated tumors). In addition, expression profiles in chromophobic RCC samples were markedly greater than that of clear cell and papillary subtypes.

According to a survey across diverse normal human tissues, miR-34a was downregulated in most human normal tissues, including renal cortex and medulla (data source: U133plus2 Affymetrix microarray from http://BioGPS.org). Consistent with our findings in renal cancer tissues, miRNA-34a has been reported to support cell proliferation in oxidative stress-induced renal carcinogenesis rat model [36] and it has been found to be overexpressed in various types of human cancer [37-40]. As one of the upregulated miRNAs in RCC, it has been speculated to function by downregulating tumor suppressor genes including secreted frizzled-related protein 1 (SFRP1) [41]. In addition, miR- 

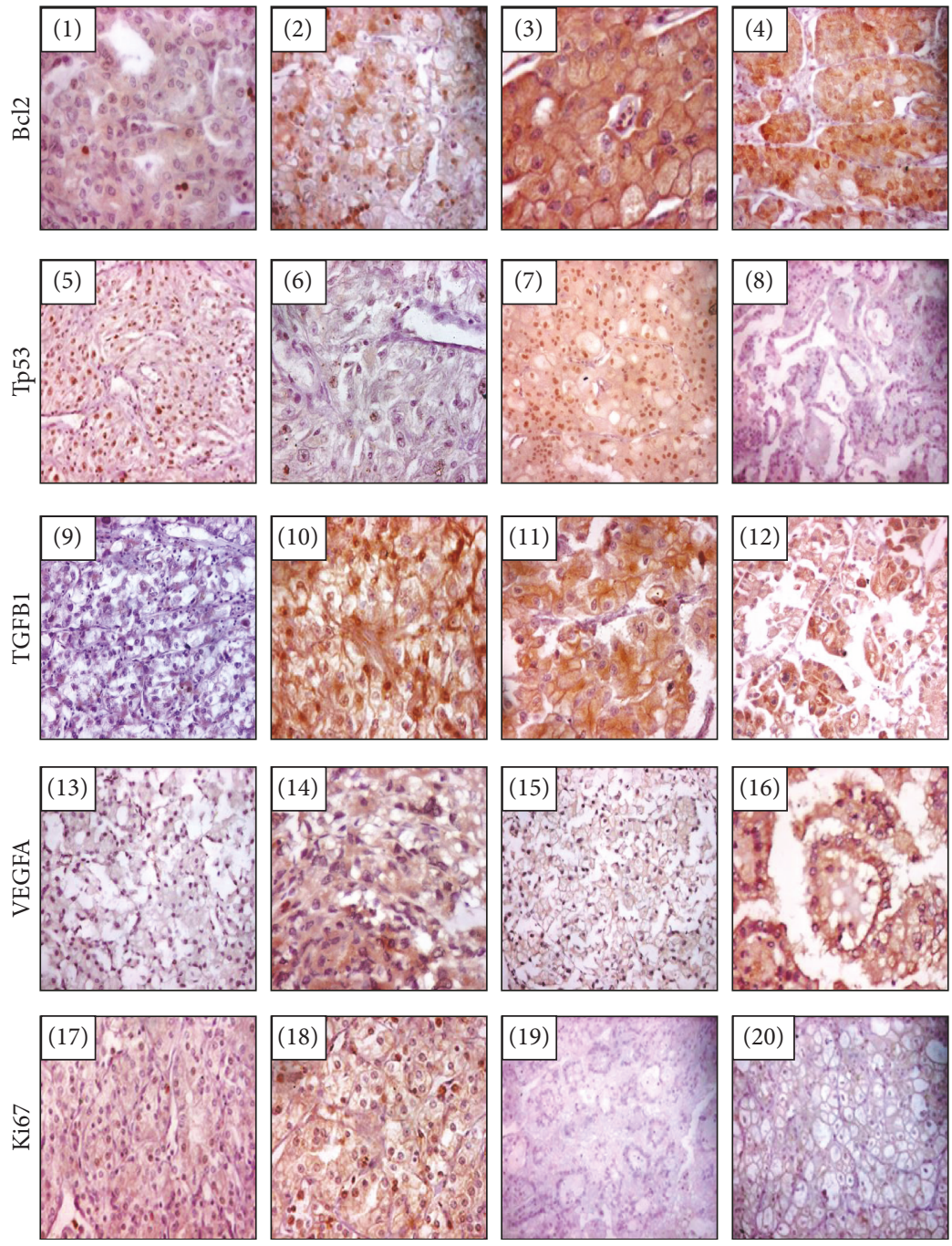

Figure 6: Immunohistochemistry images according to type and grade of RCC. Clear cell RCC (Ng1) weakly expresses bcl2 (x100), (photo 1), clear cell RCC (Ng2) with focal strong cytoplasmic bcl2 (x100) (photo 2), chromophobe RCC (Ng2) with diffuse moderate expression of bcl2 (x400) (photo 3), and papillary RCC (Ng2) with diffuse strong expression of bcl2 (x200) (photo 4). Clear cell RCC (Ng1/2) with diffuse strong nuclear expression of P53 (x100) (photo 5), clear cell RCC clear cell RCC (Ng3) showed scarce cell nuclei express P53 (X200) (photo 6), chromophobe RCC (Ng2) diffusely and strongly express P53 (X100) (photo 7), and papillary RCC do not express p53 (x100) (photo 8). Clear cell RCC (Ng2) with weak expression of TGFB1 (x100) (photo 9), RCC (Ng3) with strong expression of TGFB1 (x200) (photo 10), chromophobe RCC with focal strong expression of TGFB1 (X200) (photo 11), and papillary with focal strong expression of TGFB1 (X200) (photo 12). Clear cell RCC (Ng1) with diffuse weak expression of VEGFR (X100) (photo 13), clear RCC (Ng3) with diffuse moderate expression of VEGFR (X200) (photo 14), chromophobe RCC with weak expression of VEGF (X100) (photo 15), papillary RCC with intermediate expression of VEGFR (X200) (photo 16). RCC (Ng2) with low expression of Ki67 (X100) (photo 17), RCC (Ng3) with high expression of Ki67 (X200) (photo 18), and papillary RCC does not express Ki 67 (x100) (photo 19), and chromophobe RCC do not express Ki67 (x200) (photo 20).

34a was identified to be a direct target of the tumor suppressor Tp53 protein in human and mouse cells and mediates some of its proapoptotic biological functions [42, 43]. Similarly, $\mathrm{He}$ et al. found that deregulation of miR-34a on response to DNA damage and oncogenic stress depends on p53 in vitro and in vivo [13].

In vitro, miR-34a was coexpressed with $\mathrm{Tp} 53$ at high levels in colorectal cancer cell lines and in irradiated mice but was not expressed in Tp53-knockout mice [44]. These findings could explain the good prognosis that is implied by higher levels of miR-34a in the current samples with low pathological grade and in chromophobic RCC subtype. It has been found that miR-34a expression could suppress the cell proliferation $[38,44]$, promote apoptosis through the induction of caspase-dependent apoptotic pathways $[42,45]$ in several cancer cell lines [46-48], and cause dramatic reprogramming of gene targets that regulate apoptosis, DNA repair, cell cycle progression, epithelial-mesenchymal transition, and angiogenesis [42, 49]. In addition, miR-34a restoration in cancer cells was shown to induce cell cycle arrest at G1 and G2/M phases and sensitized the cells to chemo- and radiotherapy $[16,50]$. However, low expression 


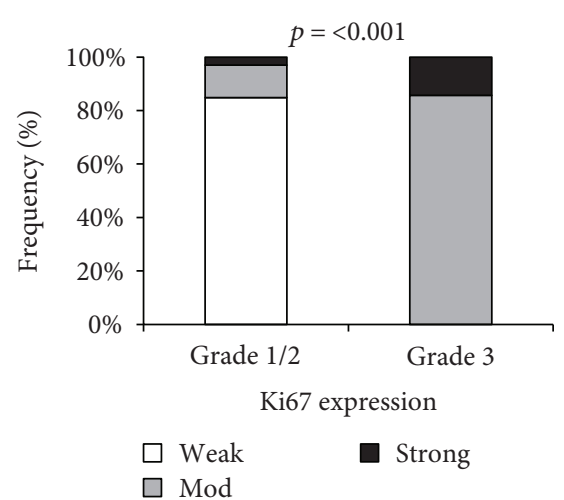

(a)

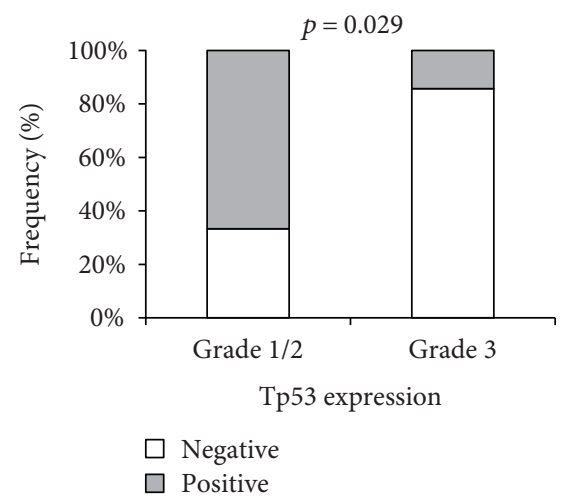

(d)

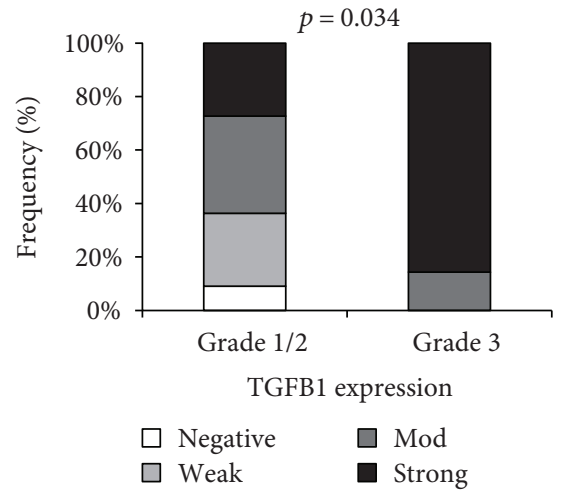

(b)

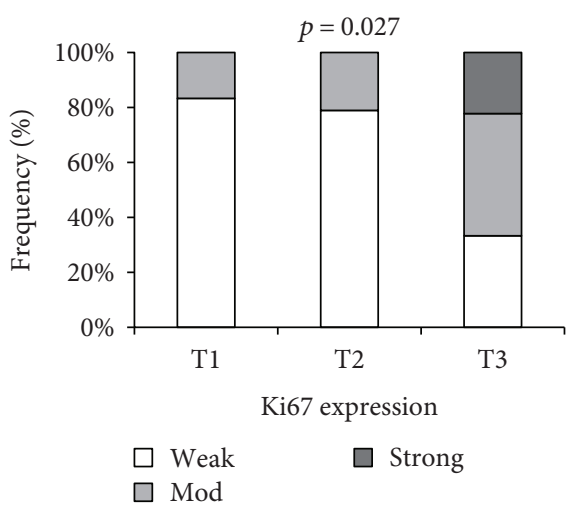

(e)

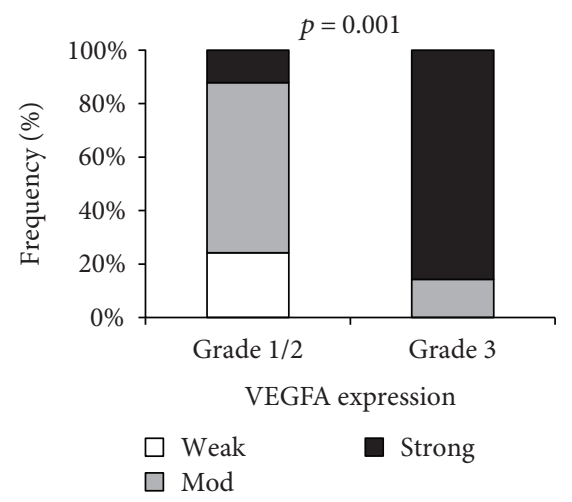

(c)

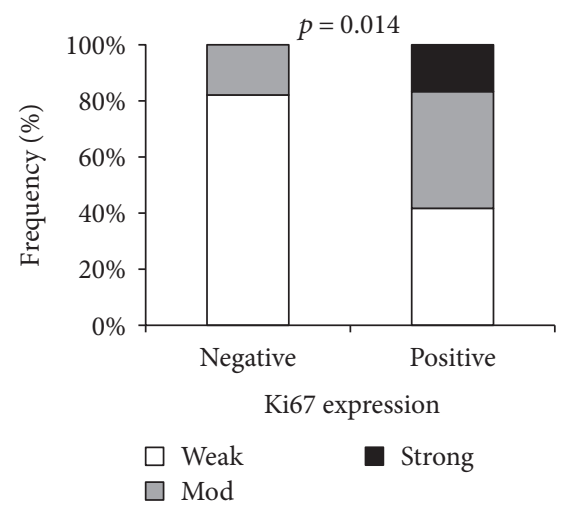

(f)

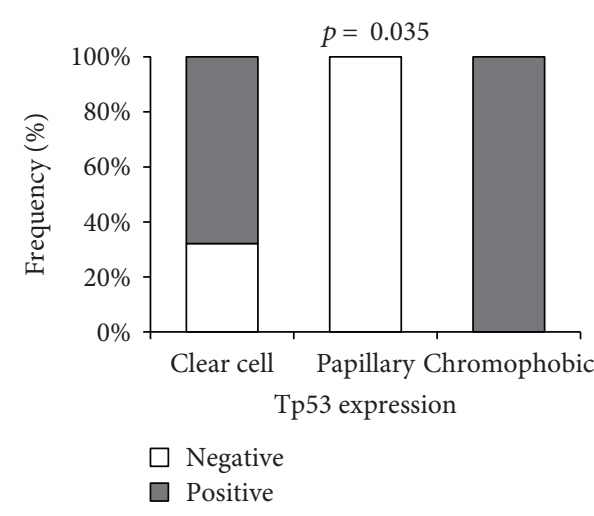

(g)

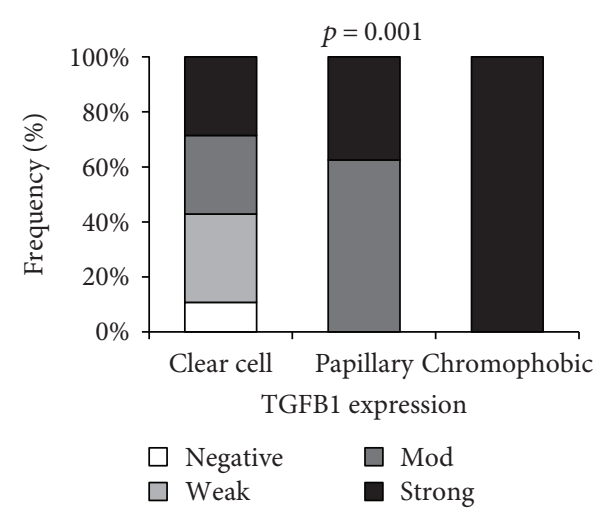

(h)

FIGURE 7: Association of immunohistochemistry markers with the clinicopathological features in RCC patients. The figures illustrated higher intensity of Ki67, TGFB1, VEGFA, and Tp53 in RCC tumors with advanced pathological grade (a-d), extensive staining of Ki67 antibodies in T3 samples and capsular infiltration (e-f), and differential expression of Tp53 and TGFB1 in various histopathological subtypes (g-h).

of miR-34a was noted in other types of cancer [46, 51-54], in glioblastoma and glioma with mutant Tp53 [55], in chronic lymphocytic lymphoma with Tp53 deletion [56], and in metastatic hepatocellular carcinoma [57], reflecting that miRNA34a can work in a cell type-specific manner with a differential p53 pathway inactivation [36].

Taken our results with the findings of prior studies, we could support the hypothesis that miR-34a overexpression in the current study is a secondary consequence in cancer cells elucidated to compete the DNA damage and uncontrolled growth proliferation. Accumulation of further mutations in higher pathological grade tumors, especially those related to Tp53 gene activity or $1 \mathrm{p} 36$ locus itself, could account for the fall of miR-34a expression profile in those patients. Further functional studies are recommended to unravel the molecular mechanisms underlying the chromophobic RCC which has the best prognosis among all other subtypes in our cases [58-60].

In silico analysis of miR-34a targets in databases revealed numerous candidate gene targets. Functional annotation and enrichment analysis showed high linkage of miR-34a with cancer-related pathways. It can influence several pathways involved in all cancer hallmarks acquired during the multistep development of human tumors, by 


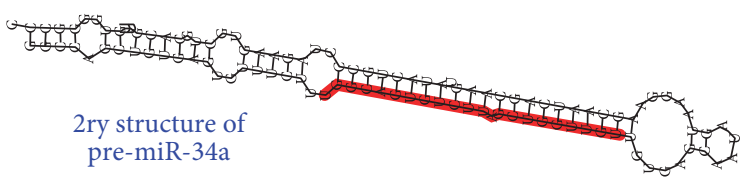

(a)

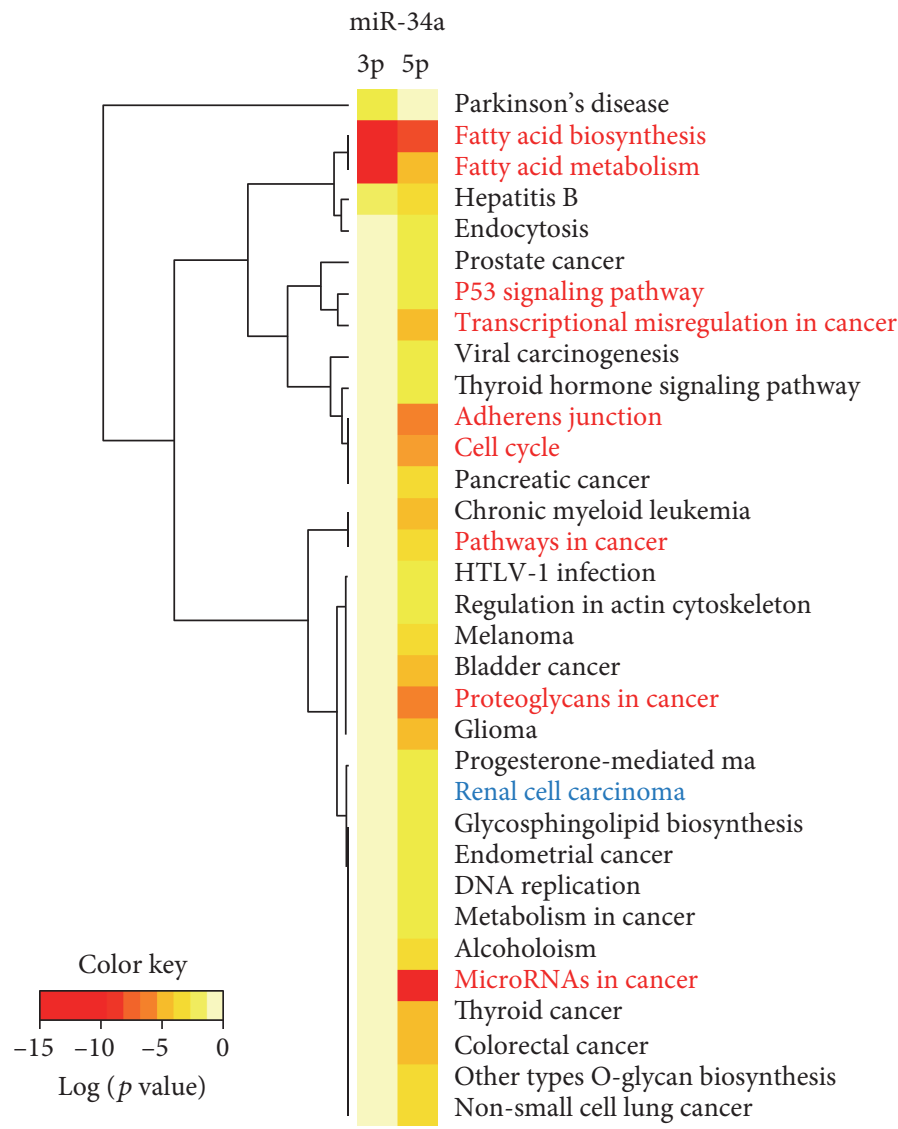

(b)

FIGURE 8: Structural analysis of MIR-34A gene locus and transcripts. (a) Homo sapiens hairpin secondary structure of pre-miR-34a stemloop. Mature miR-34a-5p highlighted in red [data source: miRTarBase v20]. (b) Enrichment pathway analysis for miR-34a. Heat map showing targeted pathways, diseases, and cancers for both hsa-miR-34a-5p and hsa-miR-34a-3p with $p$ values $<0.05$ and microT-CDS threshold 0.4. A total of 33 pathways have target genes (in CDS or $3^{\prime}$ UTR regions) for miR-34a. The enrichment results of validated target genes showed that most pathways were related to cancer and cancer-related pathways. KEGG pathway annotations related specifically to current RCC work had been labeled (red). Degree of color is based on the significant $p$ values of the predicted algorithm by DIANA tools; the red has the top significance estimated by false discovery rate (data source: DIANA-miRPath v2.0 web server).

sustaining proliferative cell signaling, evading growth suppressors, resisting apoptosis, inducing angiogenesis, and activating invasion and metastasis. In the current study, we identified predicted putative miR-34a binding sites within the $3^{\prime}$ UTR, 5'UTR, or coding regions of eleven mRNAs. These selected genes were functionally validated in prior experiments listed in Supplementary Table S1. Nevertheless, our data did not reveal inverse correlations of these targets with miR-34a. This could be explained by the fact that their gene expressions result from several integrated cell responses and cross talk between signaling pathways. Additionally, according to miRNA databases, there are multiple-tomultiple relationships between microRNAs and target genes; one miRNA may regulate transcription of many genes, and a single gene could be targeted by multiple miRNAs simultaneously, thus forming complex genetic circuits in human cancer $[61,62]$. Liu et al., in addition, speculated the identified putative targets of miRNA could be regulated by translation inhibition rather than degradation. Subsequently, this would leave mRNA levels unaffected but reduce the protein levels. This speculation warrants the need of protein level measurement in tumor/normal samples along with the miRNA and mRNA levels for the same gene to identify such type of regulation [41].

Of the deregulated target genes expressed significantly in the current renal cancer specimens, MET and E2F3 were significantly upregulated in RCC compared to noncancer tissues with high diagnostic performance. The Met protooncogene, mapped at $7 \mathrm{q} 31.2$, has two alternative spliced isoforms (http://genecards.org). We identified two 
putative miR-34a binding sites within the $3^{\prime}$ UTR and $5^{\prime}$ UTR of the human c-Met mRNA. Similarly, Li et al. [16] and $\mathrm{Hu}$ et al. [17] reported that c-Met is directly targeted by miR-34a. The MET gene encodes a receptor tyrosine kinase that is activated by hepatocyte growth factor (HGF) [16]. Ligand binding at the cell surface induces autophosphorylation of carboxyl terminus of MET on its intracellular domain that generates docking sites for second messengers, which activate several signaling pathways involving RAS-ERK, mitogen-activated protein kinase (MAPK), phosphatidylinositol 3-kinase- (PI3K-) AKT, signal transducer and activator of transcription (STAT), and phospholipase C [63]. Such downstream signaling pathways evoke a variety of pleiotropic physiological processes, including survival, morphogenesis, differentiation, epithelialmesenchymal transition, and regulation of cell migration [64]. However, improper activation of c-MET may confer proliferative and invasive/metastatic abilities of cancer cells [65]. Similar to our findings in RCC patients, MET overexpression was associated with multiple human cancers $[63,66-71]$. Its aberrant expression by different mechanisms, including point mutations [72], gene amplification [73], and oncogenic deletion [74, 75, 76], may lead to a more aggressive cancer phenotype and may be a prognostic indicator of poor overall survival and resistance to therapy [74-76].

The second upregulated gene in most of the current RCC samples was the transcription factor E2F3. ROC analysis showed its high discrimination accuracy in RCC diagnosis. In addition, its expression profile was associated with capsular infiltration. E2F3 gene lies on chromosome 6 p22.3 and has 3 transcript variants encoding 3 proteins of 465, 334, and 128 amino acids long. In contrast to full-length E2F3 protein, which is expressed only at the G1/S boundary, truncated isoforms are expressed throughout the cell cycle $[77,78]$. E2F3 recognizes a specific sequence motif in DNA and interacts directly with the tumor suppressor retinoblastoma protein $(\mathrm{pRB})$ to regulate the expression of genes involved in the G1/S boundary of the cell cycle and DNA replication; hence, E2F3 has a critical role in the control of cellular proliferation [79]. Acute loss of E2F3 activity affected the expression of genes encoding DNA replication and mitotic activities [80]. In vitro and in vivo studies showed a failure of division and proliferation in E2F3-null retinal progenitor cells [81] and early embryonic death in E2F3-null mice $[82,83]$. Dysregulation of E2F3 and altered copy number and activity of this gene have been observed in a number of malignant tumors [84-92] and correlated with several pathological features of cancer like the pathological grade and tumor cell proliferation rate [91], as well as tumor aggressiveness and poor overall survival [91, 92]. However, transgenic mice expressing inducible E2F3 resulted in hyperplasia, but not tumor development [93], supporting its role in tumor progression rather than initiation.

As an excellent marker to determine the growth fraction of a given cell population, the expression of proliferationrelated Ki67 antigen was investigated in the current study. The fraction of Ki67 positive cells is often correlated with the clinical course of the tumors. Currently, this marker of proliferation was detected in all cases of RCC, but with variable levels of expression. High expression of Ki67 was associated with advanced pathological grade, large tumor size, lymphatic invasion, and capsular infiltration. In addition, strong staining was correlated with chromophobic RCC subtype. Antigen $\mathrm{Ki} 67$ is a nuclear protein, encoded by MKI67 gene that is mapped at $10 \mathrm{q} 26.2$. It has five splice variants; only two of them are translated to synthesize a long form (3256 aa/ $395 \mathrm{kDa})$ and a short form $(2896 \mathrm{aa} / 345 \mathrm{kDa})$ proteins that differ only by the presence or absence of exon 7 [94]. Antigen Ki67 is associated with cellular proliferation [95]. During interphase, the Ki67 protein can be exclusively detected within the cell nucleus, whereas in mitosis, most of the protein is relocated to the surface of the chromosomes [96]. Ki67 protein is present during all active phases of the cell cycle (G1, S, G2, and mitosis) but is absent from resting cells (G0) [95, 97]. GO annotation identified the gene to play vital roles in chromosomal segregation regulation and organization, nuclear division, cell cycle, organ regeneration, and stress response (http://genecards.org). It is also associated with ribosomal RNA transcription and synthesis $[98,99]$. Several lines of evidence have implicated the importance of Ki67 index in multiple cancers [100-106] and reported its prognostic value for survival and tumor recurrence [107-114].

Regarding the TGFB superfamily proteins, they were known to be implicated in cell growth and differentiation. These growth factors bind various TGF-beta receptors, leading to recruitment and activation of SMAD family transcription factors which regulate the expression of the downstream genes, including interferon gamma and tumor necrosis factor alpha [115]. We examined the expression profile of TGFB1 protein and TGFB3 gene. In RCC samples, TGFB3 mRNA did not show differential expression compared to noncancer tissues. However, TGFB1 protein showed moderate to strong cytoplasmic staining in most samples. Higher protein level expression was associated with poor tumor differentiation and chromophobic subtype. This protein is involved in embryogenesis and cell differentiation and may play an important role in apoptosis, immune defense, inflammation, and tissue repair $[115,116]$. Overexpression or alterations of its active protein induced by gene somatic mutations were frequently observed in several tumor cells [117-121] and were correlated with tumor aggressiveness, invasion, angiogenesis, metastasis, immune surveillance inhibition [122], and epithelial-mesenchymal transformation [117].

SOX2 is a critical transcription factor for self-renewal and maintenance of undifferentiated embryonic stem cells [123]. SOX2 gene is mapped at 3q26.33, consisting of a single exon that encodes a protein of 318 amino acid residues (http://genecards.org). It was reported to be involved in embryonic development regulation and in the cell fate determination, and its over expression can induce reprogramming of somatic cells to acquire pluripotency characteristics $[124,125]$. SOX2 was identified as an oncogenic factor and was reported to be overexpressed in certain types of cancer [123, 126-129]. Knockdown of SOX2 could inhibit cell viability and tumorigenesis in vitro and in vivo [123, 126] by potentiating cell cycle arrest associated with decreased levels 
of CCND1 and phosphorylated Rb and/or by upregulating of p27Kip1 level [130]. In our samples, no differential expression was observed between cancer and noncancer tissues; nevertheless, lower expression of SOX2 mRNA was correlated with cancer infiltration of renal pelvic tissues.

In the current study, one antiapoptotic and three proapoptotic miR-34a targets regulating essential cancer-related pathways were examined. The apoptotic regulator BCL2 gene, mapped at 18q21.33, has 2 alternative transcripts and encodes an integral outer mitochondrial membrane protein [131]. It has two protein isoforms, Bcl2a (5.5-Kb mRNA/ $239 \mathrm{aa})$ and $\mathrm{Bcl} 2 \mathrm{~b}(3.5-\mathrm{Kb} / 205 \mathrm{aa})$, which are identical except for the C-terminal portion. The former contains a hydrophobic tail for membrane anchorage which seems to be necessary for antiapoptotic ability [132]. Bcl2 is found on the outer membrane of mitochondria. It functions as an apoptosis inhibitor by forming complexes with caspase-9 and APAF1, thus prevent them to initiate the protease cascade and apoptosis through caspase- 3 cytochrome C-dependent activation [133]. In 2002, Marsden et al. [134] discovered that $\mathrm{Bcl} 2$ can also function independently via other pathways. $\mathrm{Bcl} 2$ constitutively blocks p53-induced apoptosis and enables the survival of colorectal cancer cells [135]. Overexpression of $\mathrm{Bcl} 2$ blocks TNF-related apoptosis-inducing ligand(TRAIL-) induced apoptosis in human lung cancer cells [136]. In addition to the antiapoptotic function, $\mathrm{Bcl} 2$ is known to regulate mitochondrial fusion and fission dynamics [137]. $\mathrm{Bcl} 2$ acts as a potent regulator of cell survival in neurons both during development and throughout adult life [138]. In cancer, overexpression of the antiapoptotic $\mathrm{Bcl} 2$ can result in a distinct cellular growth advantage due to lack of cell death, a hallmark of cancer. In the present study, Bcl2 protein was expressed in all cancer tissues. Similarly, in previous studies, Bcl2 upregulation has been reported in many types of cancer [139-142]. Moreover, it has also been associated with poor clinical outcome and shorter overall survival in cancer patients [143]. It can confer resistance to chemotherapy and radiotherapy in some types of cancer [144, 145]. In addition, targeting $\mathrm{Bcl} 2$ by miR-125a, miR-206, and miR-34a was reported to inhibit the cell proliferation and induce apoptosis in multiple cancer cells [146-148].

The tumor suppressor protein Tp53, the guardian of the genome, is essential for the carcinogenesis prevention. In the current study, it was not detected by immunohistochemistry in less than one half of the specimens. Absent staining of Tp53 protein in tumor cell nuclei was significantly associated with advanced pathological grade, while positive staining was observed in the chromophobic RCC, known to have the best prognosis. The transcription factor Tp53 is encoded by TP53 gene mapped at $17 \mathrm{p} 13.1$. This gene has a complex transcriptional expression pattern encoding 28 different mRNA variants through the use of an internal promoter in intron 4 and alternative splicing machinery. All variants could be detected in all tissues, and only 5 is exclusively transcribed in tissue-specific manner [149]; each isoform has distinct biological activity and subcellular localizations [150]. Normally, Tp53 is expressed at low levels and kept inactive through the action of MDM2 (mouse double minute 2 homolog) which promotes its degradation [150]. However, during cellular stresses or DNA damage, activated Tp53 induces cell cycle arrest for DNA repair or force apoptosis. It binds to DNA and regulates transcription of target genes that induce cell cycle arrest, apoptosis, and DNA repair [150-152]. It can trigger cell death independently of its transcriptional activity through subcellular translocation and activation of proapoptotic Bcl-2 family members [153]. Attenuation of Tp53 activity would render the cells more susceptible to further genetic damage and therefore to neoplastic transformation and tumor progression.

Another apoptotic gene, Tp53INP2, is located at 20q11.22 with 4 transcripts and encodes for 3 putative protein variants of 220,88 , and 77 amino acid long. It is thought to be a scaffold protein that is normally expressed upon induction by the Tp53 protein [154]. The protein encoded by this gene has two distinct functions depending on its cellular localization [155]. It is essential for proper autophagy, a self-degradative process that occurs at critical times in development to recycle unnecessary intracellular components and damaged organelles [156]. Tp53INP2 protein shuttles between the nucleus and the cytoplasm, depending on cellular stress conditions, and relocates in the autophagosomes during autophagy activation. It recruits Atg8-like proteins to the autophagosome membrane by interacting with the transmembrane protein VMP1 (vacuole membrane protein 1) [154]. Failure of autophagy is thought to be one of the main reasons for the accumulation of cell damage and aging [157]. In addition to its role in autophagy, it serves as a transcriptional coactivator for several nuclear receptors, such as the glucocorticoid receptor, vitamin D receptor (VDR), and peroxisome proliferator-activated receptor gamma [155], thus possess a tumor suppressor-like functionality similar to Tp53 [158, 159]. Dysregulation of Tp53INP2 expression was found differently in several types of cancer tissues [160-164]. Therefore, our results along with previous data highlight its putative role in cancer development and progression.

Low levels of the apoptotic gene, $D F F A$, were observed in almost all RCC samples. Lower expression was associated with vascular infiltration. DFFA gene is located in the same region of miR-34a at $1 \mathrm{p} 36.22$ which is commonly deleted in human tumors. DFFA plays an essential role in apoptosis. When cleaved by caspase-3, it induces the release of its partner DFFB, which in turn triggers DNA fragmentation by its nuclease activity [165]. Hence, absence of this protein could result in aberrant apoptosis, invasive growth, and metastasis [166]. Similar to our findings, downregulated DFFA expression was observed during the exponential phase of growth in several human colonic cancer cell lines [167]. DFFA $(-/-)$ mice exerted severe genomic instability and tumor progression in colon epithelial cells [168]. Moreover, low DFFA expression was associated with poor prognosis in esophageal cancer [169] and neuroblastoma tumors [170].

As angiogenesis is of central importance in the growth and metastasis of tumors [171], we investigated the expression of the angiogenesis-mediated protein, VEGFA in RCC compared to noncancer tissues. VEGFA protein expression was detected in all RCC tissues, with $80 \%$ of samples showing strong staining. Elevated levels were 
associated with advanced tumor grade. VEGFA protein is encoded by the VEGFA gene, mapped at 6p21.1, a highly polymorphic region that showed association with cancer susceptibility, aggressiveness, and therapeutic response in various tumor types [172, 173]. Alternative exon splicing can generate up to 29 transcript variants with different isoforms (http://Ensembl.org). There was also evidence for alternative translation initiation codons resulting in additional isoforms. VEGFA promotes proliferation and migration of vascular endothelial cells both in vitro and in vivo and is essential for both physiological and pathological angiogenesis [172]. This prosurvival effect is mediated via PI3-kinase/Akt signal transduction pathway [174]. In addition, it induces permeabilization of blood vessels, thus known as a vascular permeability factor [175]. It induces endothelial fenestration in vascular beds [176] and enhances vasodilatation in vitro in a dose-dependent manner [177]. In addition, VEGFA promotes apoptosis and induces expression of the antiapoptotic protein Bcl-2 [178]. In vivo, VEGFA inhibition results in abnormal embryonic blood vessel formation and extensive apoptotic changes in the vasculature of neonatal mice $[179,180]$. Within tumors, cancer cells and cancerassociated stroma are the major source of VEGFA [173]. It influences the newly formed blood vessels, but not the established ones. In agreement with our findings, VEGFA was reported to be overexpressed in several different tumor types [171, 181-183]. Anti-VEGF antibodies were implicated as potent inhibitory effectors $[184,185]$. Furthermore, VEGFA expression is correlated with tumor stage and progression. It was found to be associated with high pathological grade, tumor size, lymph node metastasis, poor prognosis, resistance to chemotherapy, and poor overall survival and outcomes in several types of cancer [171, 172, 186-189].

\section{Conclusions}

The current study does confirm the association of miR-34a overexpression with RCC in our population, suggesting its potential role in pathogenesis and progression of this type of cancer. Furthermore, chromophobic RCC subtype has been postulated to attain different transcriptomics and proteomics characteristics compared to other subtypes. It has been found to have higher MIR-34A, Tp53, Ki67, and TGFB expressions. Hence, the molecular mechanism and genes involved in this particular type need to be validated in large scale multicenter study for better disease outcome and response to treatment predictions. In addition, the exact molecular interplay between the potential miR-34a target genes is still unclear and will warrant further detailed studies. One of the limitations that need to be considered is that the protein levels of the selected target genes in tumor/normal samples were not measured along with the mRNA levels. Hence, we could not suggest if the selected potential targets could be affected by translation inhibition rather than degradation in light of absence of miRNA34a-selected targets anticorrelation. Another limitation is the lack of the functional analysis either on tumor cell lines or on RCC rat models to validate the current findings and explore the detailed biological mechanisms and the potential therapeutic roles of miR-34a in RCC. This will be considered the logic next step in our ongoing research.

\section{Abbreviations}

AUC: $\quad$ Area under curve

Bcl-2: B-cell lymphoma 2

CDKN1A: Cyclin dependent kinase inhibitor 1A

crRCC: Chromophobe renal cell carcinomas

ccRCC: Clear cell renal cell carcinomas

DFFA: DNA fragmentation factor subunit alpha

FFPE: $\quad$ Formalin-fixed paraffin embedded

HGF: Hepatocyte growth factor

ISUP: International society of urological pathology

KEGG: Kyoto encyclopedia of genes and genomes

MDM2: $\quad$ Mouse double minute 2 homolog

miR-34a: MicroRNA-34a

miRNAs: MicroRNAs

Ng: $\quad$ Nuclear grade

NSCLC: Non-small-cell lung cancer

pRCC: Papillary renal cell carcinomas

PI3K: $\quad$ Phosphatidylinositol 3-kinase

qPCR: Quantitative polymerase chain reaction

Cq: Quantitative cycle

ROC: Receiver operating characteristic

RCC: Renal cell carcinoma

pRB: Retinoblastoma protein

RT: $\quad$ Reverse transcription

SFRP1: $\quad$ Secreted frizzled-related protein 1

STAT: $\quad$ Signal transducer and activator of transcription

SOX2: $\quad$ Sex-determining region Y-box 2

TGFB: $\quad$ Transforming growth factor-beta

TP53INP: Tumor protein p53 inducible nuclear protein

UTR: Untranslated region

VEGF: Vascular endothelial growth factor

VDR: Vitamin D receptor

VMP1: Vacuole membrane protein 1.

\section{Conflicts of Interest}

The authors declare that they have no competing interests.

\section{Acknowledgments}

The authors thank the Oncology Diagnostic Unit and the Center of Excellence in Molecular and Cellular Medicine, Suez Canal University, Ismailia, Egypt for providing the facilities for performing the research work.

\section{References}

[1] K. Tang and H. Xu, "Prognostic value of meta-signature miRNAs in renal cell carcinoma: an integrated miRNA expression profiling analysis," Scientific Reports, vol. 5, article 10272, 2015.

[2] P. Cairns, "Renal Cell Carcinoma," Cancer Biomarkers, vol. 9, pp. 461-473, 2011.

[3] D. L. Lim, R. Ko, and S. E. Pautler, "Current understanding of the molecular mechanisms of kidney cancer: a primer for 
urologists," Canadian Urological Association Journal, vol. 1, pp. S13-S20, 2007.

[4] Y. Moreau and L. C. Tranchevent, "Computational tools for prioritizing candidate genes: boosting disease gene discovery," Nature Reviews. Genetics, vol. 13, pp. 523-536, 2012.

[5] A. Valinezhad Orang, R. Safaralizadeh, and M. Kazemzadeh-Bavili, "Mechanisms of mirna-mediated gene regulation from common downregulation to mRNA-specific upregulation," International Journal of Genomics, vol. 2014, Article ID 970607, 15 pages, 2014.

[6] C. Baer, R. Claus, and C. Plass, "Genome-wide epigenetic regulation of miRNAs in cancer," Cancer Research, vol. 73, pp. 473-477, 2013.

[7] E. A. Toraih, M. S. Fawz, M. G. Elgazzaz, M. H. Hussein, R. H. Shehata, and H. G. Daoud, "Combined genotype analyses of precursor miRNA196a2 and 499a variants with hepatic and renal cancer susceptibility a preliminary study," Asian Pacific Journal of Cancer Prevention, vol. 17, pp. 3369-3375, 2016.

[8] E. A. Toraih, M. S. Fawzy, E. A. Mohammed, M. H. Hussein, and M. M. El-Labban, "MicroRNA-196a2 biomarker and targetome network analysis in solid tumors," Molecular Diagnosis \& Therapy, vol. 20, pp. 559-577, 2016.

[9] C. Grange, F. Collino, M. Tapparo, and G. Camussi, "Oncogenic micro-RNAs and renal cell carcinoma," Frontiers in Oncology, vol. 4, p. 49, 2014.

[10] H. Hermeking, "The miR-34 family in cancer and apoptosis," Cell Death and Differentiation, vol. 17, pp. 193-199, 2010.

[11] L. Li, "Regulatory mechanisms and clinical perspectives of miR-34a in cancer," Journal of Cancer Research and Therapeutics, vol. 10, pp. 805-810, 2014.

[12] M. Ghandadi and A. Sahebkar, "MicroRNA-34a and its target genes: key factors in cancer multidrug resistance," Current Pharmaceutical Design, vol. 22, pp. 933-939, 2016.

[13] L. He, X. He, L. P. Lim et al., "A microRNA component of the p53 tumour suppressor network," Nature, vol. 447, pp. 1130-1134, 2007

[14] G. Genovese, A. Ergun, S. A. Shukla et al., "microRNA regulatory network inference identifies miR-34a as a novel regulator of TGF- $\beta$ signaling in glioblastoma," Cancer Discovery, vol. 2, pp. 736-749, 2012.

[15] D. Reimer, M. Hubalek, H. Kiefel et al., "Regulation of transcription factor E2F3a and its clinical relevance in ovarian cancer," Oncogene, vol. 30, pp. 4038-4049, 2011.

[16] N. Li, H. Fu, Y. Tie et al., "miR-34a inhibits migration and invasion by down-regulation of c-Met expression in human hepatocellular carcinoma cells," Cancer Letters, vol. 275, pp. 44-53, 2009.

[17] Y. Hu, A. M. Correa, A. Hoque et al., "Prognostic significance of differentially expressed miRNAs in esophageal cancer," International Journal of Cancer, vol. 128, pp. 132143, 2011.

[18] G. Yu, W. Yao, W. Xiao, H. Li, H. Xu, and B. Lang, "MicroRNA-34a functions as an anti-metastatic microRNA and suppresses angiogenesis in bladder cancer by directly targeting CD44," Journal of Experimental \& Clinical Cancer Research, vol. 33, p. 779, 2014.

[19] I. S. Vlachos, K. Zagganas, M. D. Paraskevopoulou et al., "DIANA-miRPath v3.0: deciphering microRNA function with experimental support," Nucleic Acids Research, vol. 43, pp. W460-W466, 2015.
[20] C. H. Chou, N. W. Chang, S. Shrestha et al., "miRTarBase 2016: updates to the experimentally validated miRNA-target interactions database," Nucleic Acids Research, vol. 44, pp. D239-D247, 2016.

[21] I. S. Vlachos, M. D. Paraskevopoulou, D. Karagkouni et al., "DIANA-TarBase v7.0: indexing more than half a million experimentally supported miRNA:mRNA interactions," Nucleic Acids Research, vol. 43, pp. D153-D159, 2015.

[22] D. Betel, M. Wilson, A. Gabow, D. S. Marks, and C. Sander, "The microRNA.org resource: targets and expression," Nucleic Acids Research, vol. 36, pp. D149-D153, 2008.

[23] D. Szklarczyk, A. Franceschini, S. Wyder et al., "STRING v10: protein-protein interaction networks, integrated over the tree of life," Nucleic Acids Research, vol. 43, pp. D447D452, 2015.

[24] E. M. Wagner, "Monitoring gene expression: quantitative real-time RT-PCR," Methods in Molecular Biology, vol. 1027, pp. 19-45, 2013.

[25] S. A. Bustin, V. Benes, J. A. Garson et al., "The MIQE guidelines: minimum information for publication of quantitative real-time PCR experiments," Clinical Chemistry, vol. 55, pp. 611-622, 2009.

[26] J. Srigley, B. Delahunt, J. Eble et al., "The International Society of Urological Pathology (ISUP) Vancouver classification of renal neoplasia," The American Journal of Surgical Pathology, vol. 37, pp. 1469-1489, 2013.

[27] S. Fuhrman, L. C. Lasky, and L. Limas, "Prognostic significance of morphologic parameters in renal cell carcinoma," The American Journal of Surgical Pathology, vol. 6, pp. 655663, 1982.

[28] L. H. Sobin, C. Wittekind, and International Union Against Cancer (UICC), TNM Classification of Malignant Tumors, New York, 1997.

[29] D. L. Uhlman, P. L. Nguyen, J. C. Manivel et al., “Association of immunohistochemical staining for p53 with metastatic progression and poor survival in patients with renal cell carcinoma," Journal of the National Cancer Institute, vol. 86, pp. 1470-1475, 1994.

[30] A. F. Olumi, N. Weidner, and J. C. Presti, "P53 immunoreactivity correlates with $\mathrm{Ki}-67$ and bcl-2 expression in renal cell carcinoma," Urologic Oncology, vol. 6, pp. 63-67, 2001.

[31] A. Bishoy, B. Gayed, R. Youssef et al., "Ki67 is an independent predictor of oncological outcomes in patients with localized clear-cell renal cell carcinoma," BJU International, vol. 113, pp. 668-673, 2014.

[32] J. P. Kallio, P. Hirvikoski, H. Helin et al., "Renal cell carcinoma MIB-1, Bax and Bcl-2 expression and prognosis," The Journal of Urology, vol. 172, pp. 2158-2161, 2004.

[33] D. Mitropoulos, A. Kiroudi, E. Christelli et al., "Expression of transforming growth factor $\beta$ in renal cell carcinoma and matched non-involved renal tissue," Urological Research, vol. 32, pp. 317-322, 2004.

[34] S. Ambs, W. P. Bennett, W. G. Merriam et al., "Vascular endothelial growth factor and nitric oxide synthase expression in human lung cancer and the relation to p53," British Journal of Cancer, vol. 78, pp. 233-239, 1998.

[35] K. J. Livak and T. D. Schmittgen, "Analysis of relative gene expression data using real-time quantitative PCR and the $2_{\mathrm{T}}^{-\Delta \Delta \mathrm{C}}$ method," Methods, vol. 25, pp. 402-408, 2001.

[36] K. K. Dutta, Y. Zhong, Y. T. Liu et al., "Association of microRNA-34a overexpression with proliferation is cell 
type-dependent," Cancer Science, vol. 98, pp. 1845-1852, 2007.

[37] H. He, K. Jazdzewski, W. Li et al., "The role of microRNA genes in papillary thyroid carcinoma," Proceedings of the National Academy of Sciences of the United States of America, vol. 102, pp. 19075-19080, 2005.

[38] H. Tazawa, N. Tsuchiya, M. Izumiya, and H. Nakagama, "Tumor-suppressive miR-34a induces senescence-like growth arrest through modulation of the E2F pathway in human colon cancer cells," Proceedings of the National Academy of Sciences of the United States of America, vol. 104, pp. 15472-15477, 2007.

[39] E. E. Marsh, Z. Lin, P. Yin, M. Milad, D. Chakravarti, and S. E. Bulun, "Differential expression of microRNA species in human uterine leiomyoma versus normal myometrium," Fertility and Sterility, vol. 89, pp. 1771-1776, 2008.

[40] D. Asslaber, J. D. Pión, I. Seyfried et al., "microRNA-34a expression correlates with MDM2 SNP309 polymorphism and treatment-free survival in chronic lymphocytic leukemia," Blood, vol. 115, pp. 4191-4197, 2010.

[41] H. Liu, A. R. Brannon, A. R. Reddy et al., "Identifying mRNA targets of microRNA dysregulated in cancer: with application to clear cell renal cell carcinoma," BMC Systems Biology, vol. 4, p. 51, 2010.

[42] T.-C. Chang, E. A. Wentzel, O. A. Kent et al., "Transactivation of miR-34a by p53 broadly influences gene expression and promotes apoptosis," Molecular Cell, vol. 26, pp. 745752, 2007.

[43] V. Tarasov, P. Jung, B. Verdoodt et al., "Differential regulation of microRNAs by p53 revealed by massively parallel sequencing: miR-34a is a p53 target that induces apoptosis and G1-arrest," Cell Cycle, vol. 6, pp. 86-1593, 2007.

[44] C. Welch, Y. Chen, and R. L. Stallings, "MicroRNA-34a functions as a potential tumor suppressor by inducing apoptosis in neuroblastoma cells," Oncogene, vol. 26, pp. 5017-5022, 2007.

[45] N. Raver-Shapira, E. Marciano, E. Meiri et al., "Transcriptional activation of miR-34a contributes to p53-mediated apoptosis," Molecular Cell, vol. 26, pp. 731-743, 2007.

[46] C. L. Dalgard, M. Gonzalez, J. E. Deniro, and J. M. O'Brien, "Differential microRNA-34a expression and tumor suppressor function in retinoblastoma cells," Investigative Ophthalmology \& Visual Science, vol. 50, pp. 4542-4551, 2009.

[47] Z. L. Ma, P. P. Hou, Y. L. Li et al., "MicroRNA-34a inhibits the proliferation and promotes the apoptosis of non-small cell lung cancer H1299 cell line by targeting TGF $\beta$ R2," Tumour Biology, vol. 36, pp. 2481-2490, 2015.

[48] Y. Fujita, K. Kojima, N. Hamada et al., "Effects of miR-34a on cell growth and chemoresistance in prostate cancer PC3 cells," Biochemical and Biophysical Research Communications, vol. 377, pp. 114-119, 2008.

[49] Q. Ji, X. Hao, M. Zhang et al., "MicroRNA miR-34 inhibits human pancreatic cancer tumor-initiating cells," PLoS One, vol. 4, no. 8, article e6816, 2009.

[50] V. P. Tryndyak, S. A. Ross, F. A. Beland, and I. P. Pogribny, "Down-regulation of the microRNAs miR-34a, miR-127, and miR-200b in rat liver during hepatocarcinogenesis induced by a methyl-deficient diet," Molecular Carcinogenesis, vol. 48, pp. 479-487, 2008.
[51] M. Guled, L. Lahti, P. M. Lindholm et al., "CDKN2A, NF2, and JUN are dysregulated among other genes by miRNAs in malignant mesothelioma-a miRNA microarray analysis," Genes, Chromosomes \& Cancer, vol. 48, pp. 615623, 2009.

[52] D. Yan, X. Zhou, X. Chen et al., "MicroRNA-34a inhibits uveal melanoma cell proliferation and migration through downregulation of c-Met," Investigative Ophthalmology \& Visual Science, vol. 50, pp. 1559-1565, 2009.

[53] I. Satzger, A. Mattern, U. Kuettler et al., "MicroRNA-15b represents an independent prognostic parameter and is correlated with tumor cell proliferation and apoptosis in malignant melanoma," International Journal of Cancer, vol. 126, pp. 2553-2562, 2010.

[54] K. Kozaki, I. Imoto, S. Mogi, K. Omura, and J. Inazawa, "Exploration of tumor-suppressive microRNAs silenced by DNA hypermethylation in oral cancer," Cancer Research, vol. 68, pp. 2094-2105, 2008.

[55] Y. Li, F. Guessous, Y. Zhang et al., "MicroRNA-34a inhibits glioblastoma growth by targeting multiple oncogenes," Cancer Research, vol. 69, pp. 7569-7576, 2009.

[56] M. K. Dijkstra, K. Lomvan, D. Tielemans et al., “17p13/TP53 deletion in B-CLL patients is associated with microRNA-34a downregulation," Leukemia, vol. 23, pp. 625-627, 2009.

[57] A. Budhu, H. L. Jia, M. Forgues et al., "Identification of metastasis-related microRNAs in hepatocellular carcinoma," Hepatology, vol. 47, pp. 897-907, 2008.

[58] M. W. Kattan, V. Reuter, R. J. Motzer, J. Katz, and P. Russo, "A postoperative prognostic nomogram for renal cell carcinoma," The Journal of Urology, vol. 166, pp. 6367, 2001.

[59] M. F. Dall'Oglio, A. A. Antunes, A. C. Pompeo, A. Mosconi, K. R. Leite, and M. Srougi, "Prognostic relevance of the histological subtype of renal cell carcinoma," International Braz J Urol, vol. 34, pp. 3-8, 2008.

[60] V. F. Muglia and A. Prando, "Renal cell carcinoma: histological classification and correlation with imaging findings," Radiologia Brasileira, vol. 48, pp. 166-174, 2015.

[61] Y. Hashimoto, Y. Akiyama, and Y. Yuasa, "Multiple-tomultiple relationships between microRNAs and target genes in gastric cancer," PLoS One, vol. 8, article e62589, 2013.

[62] T. Kunej, I. Godnic, S. Horvat, M. Zorc, and G. A. Calin, "Cross talk between microRNA and coding cancer genes," Cancer Journal (Sudbury Mass), vol. 18, pp. 223-231, 2012.

[63] J. R. Sierra and M.-S. Tsao, "c-MET as a potential therapeutic target and biomarker in cancer," Therapeutic Advances in Medical Oncology, vol. 3, pp. S21-S35, 2011.

[64] J. R. Sierra, S. Corso, L. Caione et al., "Tumor angiogenesis and progression are enhanced by Sema4D produced by tumor-associated macrophages," The Journal of Experimental Medicine, vol. 205, pp. 1673-1685, 2008.

[65] S. Benvenuti and P. M. Comoglio, "The MET receptor tyrosine kinase in invasion and metastasis," Journal of Cellular Physiology, vol. 213, pp. 316-325, 2007.

[66] M. Tokunou, T. Niki, K. Eguchi et al., "c-MET expression in myofibroblasts: role in autocrine activation and prognostic significance in lung adenocarcinoma," The American Journal of Pathology, vol. 158, pp. 1451-1463, 2001.

[67] E. Lengyel, D. Prechtel, J. H. Resau et al., "C-Met overexpression in node-positive breast cancer identifies patients with 
poor clinical outcome independent of Her2/neu," International Journal of Cancer, vol. 113, pp. 678-682, 2005.

[68] S. Koochekpour, M. Jeffers, S. Rulong et al., "Met and hepatocyte growth factor/scatter factor expression in human gliomas," Cancer Research, vol. 57, pp. 5391-5398, 1997.

[69] C. Liu, M. Park, and M. S. Tsao, “Overexpression of c-met proto-oncogene but not epidermal growth factor receptor or c-erbB-2 in primary human colorectal carcinomas," Oncogene, vol. 7, pp. 181-185, 1992.

[70] T. Furukawa, W. P. Duguid, M. Kobari, S. Matsuno, and M. S. Tsao, "Hepatocyte growth factor and Met receptor expression in human pancreatic carcinogenesis," The American Journal of Pathology, vol. 147, pp. 889-895, 1995.

[71] R. Ramirez, D. Hsu, A. Patel et al., "Over-expression of hepatocyte growth factor/scatter factor (HGF/SF) and the $\mathrm{HGF} / \mathrm{SF}$ receptor (cMET) are associated with a high risk of metastasis and recurrence for children and young adults with papillary thyroid carcinoma," Clinical Endocrinology, vol. 53, pp. 635-644, 2000.

[72] M. Olivero, G. Valente, A. Bardelli et al., "Novel mutation in the ATP-binding site of the MET oncogene tyrosine kinase in a HPRCC family," International Journal of Cancer, vol. 82, pp. 640-643, 1999.

[73] Y. Kwak, S.-I. Kim, C.-K. Park, S. H. Paek, S.-T. Lee, and S.-H. Park, "C-MET overexpression and amplification in gliomas," International Journal of Clinical and Experimental Pathology, vol. 8, pp. 14932-14938, 2015.

[74] F. BaccoDe, P. Luraghi, E. Medico et al., "Induction of MET by ionizing radiation and its role in radioresistance and invasive growth of cancer," Journal of the National Cancer Institute, vol. 103, pp. 645-661, 2011.

[75] E. C. Smyth, F. Sclafani, and D. Cunningham, "Emerging molecular targets in oncology: clinical potential of MET/ hepatocyte growth-factor inhibitors," OncoTargets and Therapy, vol. 7, pp. 1001-1014, 2014.

[76] Z. S. Zeng, M. R. Weiser, E. Kuntz et al., "c-Met gene amplification is associated with advanced stage colorectal cancer and liver metastases," Cancer Letters, vol. 265, pp. 258-269, 2008.

[77] M. R. Adams, R. Sears, F. Nuckolls, G. Leone, and J. R. Nevins, "Complex transcriptional regulatory mechanisms control expression of the E2F3 locus," Molecular and Cellular Biology, vol. 20, pp. 3633-3639, 2000.

[78] Y. He, M. K. Armanious, M. J. Thomas, and W. D. Cress, "Identification of E2F-3B, an alternative form of E2F-3 lacking a conserved N-terminal region," Oncogene, vol. 19, pp. 3422-3433, 2000.

[79] G. Leone, J. DeGregori, Z. Yan et al., "E2F3 activity is regulated during the cell cycle and is required for the induction of S phase," Genes \& Development, vol. 12, pp. 21202130, 1998

[80] L. J. Kong, J. T. Chang, A. H. Bild, and J. R. Nevins, "Compensation and specificity of function within the E2F family," Oncogene, vol. 26, pp. 321-327, 2007.

[81] D. Chen, M. Pacal, P. Wenzel, P. S. Knoepfler, G. Leone, and R. Bremner, "Division and apoptosis of E2f-deficient retinal progenitors," Nature, vol. 462, pp. 925-929, 2009.

[82] L. Wu, C. Timmers, B. Maiti et al., "The E2F1-3 transcription factors are essential for cellular proliferation," Nature, vol. 414, pp. 457-462, 2001.
[83] S.-Y. Tsai, R. Opavsky, N. Sharma et al., "Mouse development with a single E2F activator," Nature, vol. 454, pp. 1137-1141, 2008.

[84] M. Y. Lee, C. S. Moreno, and H. Saavedra, "E2F activators signal and maintain centrosome amplification in breast cancer cells," Molecular and Cellular Biology, vol. 34, pp. 25812599, 2014.

[85] Q. An, Y. Wang, R. An et al., "Association of E2F3 expression with clinicopathological features of Wilms' tumors," Journal of Pediatric Surgery, vol. 48, pp. 2187-2193, 2013.

[86] C. S. Cooper, A. G. Nicholson, C. Foster et al., "Nuclear overexpression of the E2F3 transcription factor in human lung cancer," Lung Cancer, vol. 54, pp. 155-162, 2006.

[87] X. Zeng, F. Yin, X. Liu et al., "Upregulation of E2F transcription factor 3 is associated with poor prognosis in hepatocellular carcinoma," Oncology Reports, vol. 31, pp. 1139-1146, 2014.

[88] L. Huang, J. Luo, Q. Cai et al., "MicroRNA-125b suppresses the development of bladder cancer by targeting E2F3," International Journal of Cancer, vol. 128, pp. 17581769, 2011.

[89] M. Oeggerli, P. Schraml, C. Ruiz et al., "E2F3 is the main target gene of the 6p22 amplicon with high specificity for human bladder cancer," Oncogene, vol. 25, pp. 65386543, 2006.

[90] A. Feber, J. Clark, G. Goodwin et al., "Amplification and overexpression of E2F3 in human bladder cancer," Oncogene, vol. 23, pp. 1627-1630, 2004.

[91] A. Y. Olsson, A. Feber, S. R. Edwards et al., "Role of E2F3 expression in modulating cellular proliferation rate in human bladder and prostate cancer cells," Oncogene, vol. 26, pp. 1028-1037, 2007.

[92] C. S. Foster, A. Falconer, A. R. Dodson et al., "Transcription factor E2F3 overexpressed in prostate cancer independently predicts clinical outcome," Oncogene, vol. 23, pp. 58715879, 2004.

[93] E. Lazzerini Denchi, C. Attwooll, D. Pasini, and K. Helin, "Deregulated E2F activity induces hyperplasia and senescence-like features in the mouse pituitary gland," Molecular and Cellular Biology, vol. 25, pp. 2660-2672, 2005.

[94] C. Schluter, M. Duchrow, C. Wohlenberg et al., "The cell proliferation-associated antigen of antibody Ki-67: a very large, ubiquitous nuclear protein with numerous repeated elements, representing a new kind of cell cycle-maintaining proteins," The Journal of Cell Biology, vol. 123, pp. 513-522, 1993.

[95] T. Scholzen and J. Gerdes, "The Ki-67 protein: from the known and the unknown," Journal of Cellular Physiology, vol. 182, pp. 311-322, 2000.

[96] J. Gerdes, U. Schwab, H. Lemke, and H. Stein, "Production of a mouse monoclonal antibody reactive with a human nuclear antigen associated with cell proliferation," International Journal of Cancer, vol. 31, pp. 13-20, 1983.

[97] J. Gerdes, H. Lemke, H. Baisch, H. H. Wacker, U. Schwab, and H. Stein, "Cell cycle analysis of a cell proliferationassociated human nuclear antigen defined by the monoclonal antibody Ki-67," Journal of Immunology, vol. 133, no. 4, pp. 1710-1715, 1984.

[98] J. Bullwinkel, B. Baron-Lühr, A. Lüdemann, C. Wohlenberg, J. Gerdes, and T. Scholzen, "Ki-67 protein is associated with ribosomal RNA transcription in quiescent and 
proliferating cells," Journal of Cellular Physiology, vol. 206, pp. 624-635, 2006.

[99] R. Rahmanzadeh, G. Hüttmann, J. Gerdes, and T. Scholzen, "Chromophore-assisted light inactivation of pKi-67 leads to inhibition of ribosomal RNA synthesis," Cell Proliferation, vol. 40, pp. 422-430, 2007.

[100] R. J. Bryant, P. M. Banks, and D. P. O'Malley, "Ki67 staining pattern as a diagnostic tool in the evaluation of lymphoproliferative disorders," Histopathology, vol. 48, pp. 505-515, 2006.

[101] Y. L. Ma, J. Y. Peng, P. Zhang, W. J. Liu, L. Huang, and H. L. Qin, "Immunohistochemical analysis revealed CD34 and Ki67 protein expression as significant prognostic factors in colorectal cancer," Medical Oncology, vol. 27, pp. 304-309, 2010.

[102] R. N. Das, U. Chatterjee, S. K. Sinha, A. K. Ray, K. Saha, and S. Banerjee, "Study of histopathological features and proliferation markers in cases of Wilms' tumor," Indian Journal of Medical and Paediatric Oncology: Official Journal of Indian Society of Medical \& Paediatric Oncology, vol. 33, pp. 102106, 2012.

[103] G. Fisher, Z. H. Yang, S. Kudahetti et al., "Prognostic value of Ki-67 for prostate cancer death in a conservatively managed cohort," British Journal of Cancer, vol. 108, pp. 271-277, 2013.

[104] N. V. Shivaprasad, S. Satish, S. Ravishankar, and M. G. Vimalambike, "Ki-67 immunostaining in astrocytomas: association with histopathological grade - a South Indian study," Journal of Neurosciences in Rural Practice, vol. 7, pp. 510-514, 2016.

[105] I. Markova, M. Duskova, M. Lubusky et al., "Selected immunohistochemical prognostic factors in endometrial cancer," International Journal of Gynecological Cancer, vol. 20, pp. 576-582, 2010.

[106] K. Kontzoglou, V. Palla, G. Karaolanis et al., "Correlation between Ki67 and breast cancer prognosis," Oncology, vol. 84, pp. 219-225, 2013.

[107] E. C. Inwald, M. Klinkhammer-Schalke, F. Hofstadter et al., "Ki-67 is a prognostic parameter in breast cancer patients: results of a large population-based cohort of a cancer registry," Breast Cancer Research and Treatment, vol. 139, pp. 539-552, 2013.

[108] M. Ishihara, H. Mukai, S. Nagai et al., "Retrospective analysis of risk factors for central nervous system metastases in operable breast cancer: effects of biologic subtype and Ki67 overexpression on survival," Oncology, vol. 84, pp. 135-140, 2013.

[109] U. Kucuk, U. Bayol, E. E. Pala, and S. Cumurcu, "Importance of P53, Ki-67 expression in the differential diagnosis of benign/malignant phyllodes tumors of the breast," Indian Journal of Pathology \& Microbiology, vol. 56, pp. 129-134, 2013.

[110] S. C. Stoian, C. Simionescu, C. Margaritescu, A. Stepan, and M. Nurciu, "Endometrial carcinomas: correlation between ER, PR, Ki67 status and histopathological prognostic parameters," Romanian Journal of Morphology and Embryology, vol. 52, pp. 631-636, 2011.

[111] A. Mourtzikou, K. Kosmas, A. Marouga, M. Stamouli, A. Pouliakis, and P. Karakitsos, "The use of an immunocytochemical double-labeling staining can display the distribution of Bcl-2/Ki-67 cells in endometrial adenocarcinomas as well as in normal endometrium," Clinical Laboratory, vol. 58, pp. 133-144, 2012.
[112] U. Kucukgoz Gulec, D. Gumurdulu, A. B. Guzel et al., "Prognostic importance of survivin, Ki-67, and topoisomerase II $\alpha$ in ovarian carcinoma," Archives of Gynecology and Obstetrics, vol. 289, pp. 393-398, 2014.

[113] B. Belev, I. Brcic, J. Prejac et al., "Role of Ki-67 as a prognostic factor in gastrointestinal stromal tumors," World Journal of Gastroenterology, vol. 19, pp. 523-527, 2013.

[114] M. Preusser, R. Hoeftberger, A. Woehrer et al., "Prognostic value of Ki67 index in anaplastic oligodendroglial tumours a translational study of the European Organization for Research and Treatment of Cancer Brain Tumor Group," Histopathology, vol. 60, pp. 885-894, 2012.

[115] K. A. Harradine and R. J. Akhurst, "Mutations of TGF $\beta$ signaling molecules in human disease," Annals of Medicine, vol. 38, pp. 403-414, 2006.

[116] A. B. Roberts, "Molecular and cell biology of TGF- $\beta$," Mineral and Electrolyte Metabolism, vol. 24, pp. 111-119, 1998.

[117] J. Seoane, "Escaping from the TGF $\beta$ anti-proliferative control," Carcinogenesis, vol. 27, pp. 2148-2156, 2006.

[118] H. G. Kang, M. H. Chae, J. M. Park et al., "Polymorphisms in TGF- $\beta 1$ gene and the risk of lung cancer," Lung Cancer, vol. 52, pp. 1-7, 2006.

[119] A. Helmy, O. A. Hammam, T. R. LithyEl, and M. M. Deen WishahiEl, "The role of TGF-beta-1 protein and TGF-beta$\mathrm{R}-1$ receptor in immune escape mechanism in bladder cancer," MedGenMed, vol. 9, p. 34, 2007.

[120] V. Ivanovic, M. Demajo, K. Krtolica et al., "Elevated plasma TGF- $\beta_{1}$ levels correlate with decreased survival of metastatic breast cancer patients," Clinica Chimica Acta, vol. 371, pp. 191-193, 2006.

[121] X. Sun, S. A. Robertson, and W. V. Ingman, "Regulation of epithelial cell turnover and macrophage phenotype by epithelial cell-derived transforming growth factor betal in the mammary gland," Cytokine, vol. 61, pp. 377-388, 2013.

[122] W. Wick, M. Platten, and M. Weller, "Glioma cell invasion: regulation of metalloproteinase activity by TGF- $\beta$," Journal of Neuro-Oncology, vol. 53, pp. 177-185, 2001.

[123] C. Ren, T. Ren, K. Yang et al., "Inhibition of SOX2 induces cell apoptosis and G1/S arrest in Ewing's sarcoma through the PI3K/Akt pathway," Journal of Experimental \& Clinical Cancer Research, vol. 35, p. 44, 2016.

[124] K. Takahashi, K. Tanabe, M. Ohnuki et al., "Induction of pluripotent stem cells from adult human fibroblasts by defined factors," Cell, vol. 131, pp. 861-872, 2007.

[125] J. Yu, M. A. Vodyanik, K. Smuga-Otto et al., "Induced pluripotent stem cell lines derived from human somatic cells," Science, vol. 318, pp. 1917-1920, 2007.

[126] Y. Chen, L. Shi, L. Zhang et al., "The molecular mechanism governing the oncogenic potential of SOX2 in breast cancer," The Journal of Biological Chemistry, vol. 283, pp. 1796917978, 2008.

[127] X. Fang, W. Yu, L. Li et al., "ChIP-seq and functional analysis of the SOX2 gene in colorectal cancers," OMICS, vol. 14, pp. 369-384, 2010.

[128] E. A. Toraih, M. S. Fawzy, A. I. El-Falouji et al., "Stemnessrelated transcriptional factors and homing gene expression profiles in hepatic differentiation and cancer," Molecular Medicine, vol. 22, pp. 653-663, 2016.

[129] L. Annovazzi, M. Mellai, V. Caldera, G. Valente, and D. Schiffer, "SOX2 expression and amplification in gliomas 
and glioma cell lines," Cancer Genomics \& Proteomics, vol. 8, pp. 139-147, 2011.

[130] T. Otsubo, Y. Akiyama, K. Yanagihara, and Y. Yuasa, "SOX2 is frequently downregulated in gastric cancers and inhibits cell growth through cell-cycle arrest and apoptosis," British Journal of Cancer, vol. 98, pp. 824-831, 2008.

[131] D. Hockenbery, G. Nunez, C. Milliman, R. D. Schreiber, and S. J. Korsmeyer, "Bcl-2 is an inner mitochondrial membrane protein that blocks programmed cell death," Nature, vol. 348, pp. 334-336, 1990.

[132] Y. Tsujimoto and C. M. Croce, "Analysis of the structure, transcripts, and protein products of bcl-2, the gene involved in human follicular lymphoma," Proceedings of the National Academy of Sciences of the United States of America, vol. 83, pp. 5214-5218, 1986.

[133] A. M. Kabel, A. A. Adwas, A. A. Elkhoely, M. N. Abdel-Rahman, and A. A. Eissa, "Apoptosis: insights into pathways and role of p53, Bcl-2 and sphingosine kinases," Journal of Cancer Research and Treatment, vol. 4, pp. 69-72, 2016.

[134] V. S. Marsden, L. O'Connor, L. A. O'Reilly et al., “Apoptosis initiated by Bcl-2-regulated caspase activation independently of the cytochrome c/Apaf-1/caspase-9 apoptosome," Nature, vol. 419, pp. 634-637, 2002.

[135] M. Jiang and J. Milner, "Bcl-2 constitutively suppresses p53-dependent apoptosis in colorectal cancer cells," Genes \& Development, vol. 17, pp. 832-837, 2003.

[136] S. Y. Sun, P. Yue, J. Y. Zhou et al., "Overexpression of BCL2 blocks TNF-related apoptosis-inducing ligand (TRAIL)induced apoptosis in human lung cancer cells," Biochemical and Biophysical Research Communications, vol. 280, pp. 788-797, 2001.

[137] A. Autret and S. J. Martin, "Bcl-2 family proteins and mitochondrial fission/fusion dynamics," Cellular and Molecular Life Sciences, vol. 67, pp. 1599-1606, 2010.

[138] J. Chen, J. G. Flannery, M. M. LaVail, R. H. Steinberg, J. $\mathrm{Xu}$, and M. I. Simon, "Bcl-2 overexpression reduces apoptotic photoreceptor cell death in three different retinal degenerations," Proceedings of the National Academy of Sciences of the United States of America, vol. 93, pp. 70427047, 1996.

[139] A. Majid, O. Tsoulakis, R. Walewska et al., "BCL2 expression in chronic lymphocytic leukemia: lack of association with the BCL2 938A>C promoter single nucleotide polymorphism," Blood, vol. 111, pp. 874-877, 2008.

[140] J. Iqbal, V. T. Neppalli, G. Wright et al., "BCL2 expression is a prognostic marker for the activated B-cell-like type of diffuse large B-cell lymphoma," Journal of Clinical Oncology, vol. 24, pp. 961-968, 2006.

[141] I. Skirnisdottir, T. Seidal, E. Gerdin, and B. Sorbe, "The prognostic importance of $\mathrm{p} 53$, bcl-2, and bax in early stage epithelial ovarian carcinoma treated with adjuvant chemotherapy," International Journal of Gynecological Cancer, vol. 12, pp. 265-276, 2002.

[142] C. Wei, Q. Luo, X. Sun et al., "microRNA-497 induces cell apoptosis by negatively regulating $\mathrm{Bcl}-2$ protein expression at the posttranscriptional level in human breast cancer," International Journal of Clinical and Experimental Pathology, vol. 8, pp. 7729-7739, 2015.

[143] D. F. Mühlbeier, V. A. Saddi, É. C. Paulade et al., "Prognostic significance of apoptosis-related markers in patients with soft-tissue sarcomas of extremities," Applied
Immunohistochemistry \& Molecular Morphology, vol. 24, pp. 268-274, 2016.

[144] M. Abou El Hassan, D. C. J. Mastenbroek, W. R. Gerritsen, G. Giaccone, and F. A. E. Kruyt, "Overexpression of Bcl2 abrogates chemo- and radiotherapy-induced sensitisation of NCI-H460 non-small-cell lung cancer cells to adenovirusmediated expression of full-length TRAIL," British Journal of Cancer, vol. 91, pp. 171-177, 2004.

[145] S. H. Kim, J. N. Ho, H. Jin et al., "Upregulated expression of BCL2, MCM7, and CCNE1 indicate cisplatin-resistance in the set of two human bladder cancer cell lines: T24 cisplatin sensitive and T24R2 cisplatin resistant bladder cancer cell lines," Investigative and Clinical Urology, vol. 57, pp. 63-72, 2016.

[146] Z. Tong, N. Liu, L. Lin, X. Guo, D. Yang, and Q. Zhang, "miR-125a-5p inhibits cell proliferation and induces apoptosis in colon cancer via targeting BCL2, BCL2L12 and MCL1," Biomedicine \& Pharmacotherapy, vol. 75, pp. 129136, 2015.

[147] C. Sun, Z. Liu, S. Li et al., "Down-regulation of c-Met and Bcl2 by microRNA-206, activates apoptosis, and inhibits tumor cell proliferation, migration and colony formation," Oncotarget, vol. 6, pp. 25533-25574, 2015.

[148] L. Li, L. Yuan, J. Luo, J. Gao, J. Guo, and X. Xie, "MiR-34a inhibits proliferation and migration of breast cancer through down-regulation of Bcl-2 and SIRT1," Clinical and Experimental Medicine, vol. 13, pp. 109-117, 2013.

[149] J.-C. Bourdon, K. Fernandes, F. Murray-Zmijewski et al., "p53 isoforms can regulate p53 transcriptional activity," Genes \& Development, vol. 19, pp. 2122-2137, 2005.

[150] J.-C. Bourdon, "p53 and its isoforms in cancer," British Journal of Cancer, vol. 97, pp. 277-282, 2007.

[151] J. E. Chipuk and D. R. Green, "Dissecting p53-dependent apoptosis," Cell Death and Differentiation, vol. 13, pp. 994$1002,2006$.

[152] K. H. Vousden and D. P. Lane, "p53 in health and disease," Nature Reviews. Molecular Cell Biology, vol. 8, pp. 275-283, 2007.

[153] U. M. Moll, S. Wolff, D. Speidel, and W. Deppert, "Transcription-independent pro-apoptotic functions of p53," Current Opinion in Cell Biology, vol. 17, pp. 631-636, 2005.

[154] J. Nowak and J. L. Iovanna, “TP53INP2 is the new guest at the table of self-eating," Autophagy, vol. 5, pp. 383-384, 2009.

[155] D. Sala and A. Zorzano, "Is TP53INP2 a critical regulator of muscle mass?," Current Opinion in Clinical Nutrition and Metabolic Care, vol. 18, pp. 234-239, 2015.

[156] J. Nowak, C. Archange, J. Tardivel-Lacombe et al., "The TP53INP2 protein is required for autophagy in mammalian cells," Molecular Biology of the Cell, vol. 20, pp. 870-881, 2009.

[157] A. M. Cuervo, E. Bergamini, U. T. Brunk, W. Dröge, M. Ffrench, and A. Terman, "Autophagy and aging: the importance of maintaining "clean" cells," Autophagy, vol. 1, pp. 131-140, 2005.

[158] R. Mirzayans, B. Andrais, A. Scott, and D. Murray, "New insights into p53 signaling and cancer cell response to DNA damage: implications for cancer therapy," Journal of Biomedicine and Biotechnology, vol. 2012, Article ID 170325, 16 pages, 2012.

[159] T. A. Haj-Ahmad, M. A. Abdalla, and Y. Haj-Ahmad, "Potential urinary protein biomarker candidates for the 
accurate detection of prostate cancer among benign prostatic hyperplasia patients," Journal of Cancer, vol. 5, pp. 103-114, 2014.

[160] M. He, Y. Zhao, H. Yi, H. Sun, X. Liu, and S. Ma, "The combination of TP53INP1, TP53INP2 and AXIN2: potential biomarkers in papillary thyroid carcinoma," Endocrine, vol. 48, pp. 712-717, 2015.

[161] T. Schlomm, E. Näkel, A. Lübke et al., "Marked gene transcript level alterations occur early during radical prostatectomy," European Urology, vol. 53, pp. 333-344, 2008.

[162] E. Staub, J. Gröne, D. Mennerich et al., "A genome-wide map of aberrantly expressed chromosomal islands in colorectal cancer," Molecular Cancer, vol. 5, p. 37, 2006.

[163] A. Nordgren, M. Corcoran, A. Sääf et al., "Characterisation of hairy cell leukaemia by tiling resolution array-based comparative genome hybridisation: a series of 13 cases and review of the literature," European Journal of Haematology, vol. 84, pp. 17-25, 2010.

[164] K. Moran-Jones, J. Grindlay, M. Jones, R. Smith, and J. C. Norman, "hnRNP A2 regulates alternative mRNA splicing of TP53INP2 to control invasive cell migration," Cancer Research, vol. 69, pp. 9219-9227, 2009.

[165] S. S. Boon and S. P. Sim, "Inhibitor of caspase-activated DNase expression enhances caspase-activated DNase expression and inhibits oxidative stress-induced chromosome breaks at the mixed lineage leukaemia gene in nasopharyngeal carcinoma cells," Cancer Cell International, vol. 15, p. 54, 2015.

[166] J. Zhang, H. Guo, G. Qian et al., "MiR-145, a new regulator of the DNA fragmentation factor-45 (DFF45)-mediated apoptotic network," Molecular Cancer, vol. 9, p. 211, 2010.

[167] L. Charrier, A. Jarry, C. Toquet et al., "Growth phasedependent expression of ICADL/DFF45 modulates the pattern of apoptosis in human colonic cancer cells," Cancer Research, vol. 62, pp. 2169-2174, 2002.

[168] Y. Errami, H. Brim, K. Oumouna-Benachour et al., "ICAD deficiency in human colon cancer and predisposition to colon tumorigenesis: linkage to apoptosis resistance and genomic instability," PLoS One, vol. 8, article e57871, 2013.

[169] S. Konishi, H. Ishiguro, Y. Shibata et al., "Decreased expression of DFF45/ICAD is correlated with a poor prognosis in patients with esophageal carcinoma," Cancer, vol. 95, pp. 2473-2478, 2002.

[170] F. Abel, R. M. Sjöberg, C. Krona, S. Nilsson, and T. Martinsson, "Mutations in the N-terminal domain of DFF45 in a primary germ cell tumor and in neuroblastoma tumors," International Journal of Oncology, vol. 25, pp. 1297-1302, 2004.

[171] H. Linardou, K. T. Kalogeras, R. Kronenwett et al., "The prognostic and predictive value of mRNA expression of vascular endothelial growth factor family members in breast cancer: a study in primary tumors of high-risk early breast cancer patients participating in a randomized Hellenic Cooperative Oncology Group trial," Breast Cancer Research, vol. 14, article R145, 2012.

[172] D. Sa-Nguanraksa and P. O-Charoenrat, "The role of vascular endothelial growth factor a polymorphisms in breast cancer," International Journal of Molecular Sciences, vol. 13, pp. 14845-14864, 2012.

[173] D. Della-Morte, S. Riondino, P. Ferroni et al., "Impact of VEGF gene polymorphisms in elderly cancer patients: clinical outcome and toxicity," Pharmacogenomics, vol. 16, pp. 61-78, 2015.

[174] H. P. Gerber, A. McMurtrey, J. Kowalski et al., "Vascular endothelial growth factor regulates endothelial cell survival through the phosphatidylinositol 3'-kinase/Akt signal transduction pathway. Requirement for Flk-1/KDR activation," The Journal of Biological Chemistry, vol. 273, pp. 3033630343, 1998.

[175] H. F. Dvorak, "Vascular permeability factor/vascular endothelial growth factor: a critical cytokine in tumor angiogenesis and a potential target for diagnosis and therapy," Journal of Clinical Oncology, vol. 20, pp. 4368-4380, 2002.

[176] W. G. Roberts and G. E. Palade, "Increased microvascular permeability and endothelial fenestration induced by vascular endothelial growth factor," Journal of Cell Science, vol. 108, pp. 2369-2379, 1995.

[177] K. DD, J. K. Zaleski, S. Liu, and T. A. Brock, "Vascular endothelial growth factor induces EDRF-dependent relaxation in coronary arteries," The American Journal of Physiology, vol. 265, pp. H586-H592, 1993.

[178] H. P. Gerber, V. Dixit, and N. Ferrara, "Vascular endothelial growth factor induces expression of the antiapoptotic proteins Bcl-2 and A1 in vascular endothelial cells," The Journal of Biological Chemistry, vol. 273, pp. 13313-13316, 1998.

[179] L. E. Benjamin, D. Golijanin, A. Itin, D. Pode, and E. Keshet, "Selective ablation of immature blood vessels in established human tumors follows vascular endothelial growth factor withdrawal," The Journal of Clinical Investigation, vol. 103, pp. 159-165, 1999.

[180] H. P. Gerber, K. J. Hillan, A. M. Ryan et al., "VEGF is required for growth and survival in neonatal mice," Development, vol. 126, pp. 1149-1159, 1999.

[181] P. Delmotte, B. Martin, M. Paesmans et al., "VEGF and survival of patients with lung cancer: a systematic literature review and meta-analysis," Revue des Maladies Respiratoires, vol. 19, pp. 577-584, 2002.

[182] P. A. Kyzas, I. W. Cunha, and J. P. Ioannidis, "Prognostic significance of vascular endothelial growth factor immunohistochemical expression in head and neck squamous cell carcinoma: a meta-analysis," Clinical Cancer Research, vol. 11, pp. 1434-1434, 2005.

[183] G. Des Guetz, B. Uzzan, P. Nicolas et al., "Microvessel density and VEGF expression are prognostic factors in colorectal cancer. Meta-analysis of the literature," British Journal of Cancer, vol. 94, pp. 1823-1832, 2006.

[184] P. Borgström, M. A. Bourdon, K. J. Hillan, P. Sriramarao, and N. Ferrara, "Neutralizing anti-vascular endothelial growth factor antibody completely inhibits angiogenesis and growth of human prostate carcinoma micro tumors in vivo," The Prostate, vol. 1, no. 35, pp. 1-10, 1998.

[185] K. J. Kim, B. Li, J. Winer et al., "Inhibition of vascular endothelial growth factor-induced angiogenesis suppresses tumour growth in vivo," Nature, vol. 362, pp. 841-844, 1993.

[186] S. P. Balasubramanian, A. Cox, S. S. Cross, S. E. Higham, N. J. Brown, and M. W. Reed, "Influence of VEGF-A gene variation and protein levels in breast cancer susceptibility and severity," International Journal of Cancer, vol. 121, pp. 1009-1016, 2007.

[187] L. Rydén, M. Stendahl, H. Jonsson, S. Emdin, N. O. Bengtsson, and G. Landberg, "Tumor-specific VEGF-A and VEGFR2 in postmenopausal breast cancer patients with 
long-term follow-up. Implication of a link between VEGF pathway and tamoxifen response," Breast Cancer Research and Treatment, vol. 89, pp. 135-143, 2005.

[188] H. Han, J. F. Silverman, T. S. Santucci et al., "Vascular endothelial growth factor expression in stage I non-small cell lung cancer correlates with neoangiogenesis and a poor prognosis," Annals of Surgical Oncology, vol. 8, pp. 72-79, 2001.

[189] G. Cao, X. Li, C. Qin, and J. Li, "Prognostic value of VEGF in hepatocellular carcinoma patients treated with sorafenib: a meta-analysis," Medical Science Monitor, vol. 21, pp. 31443151, 2015. 


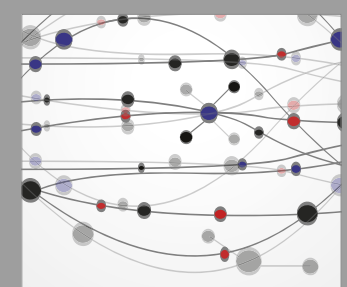

The Scientific World Journal
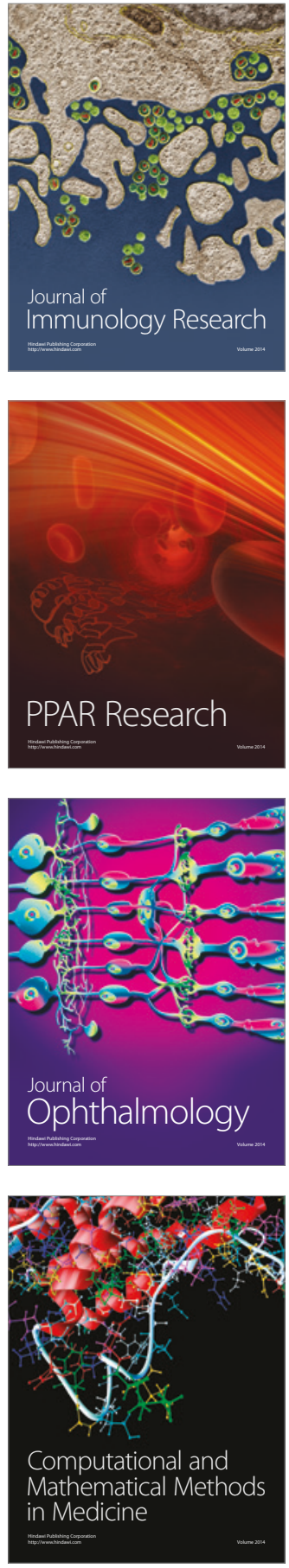

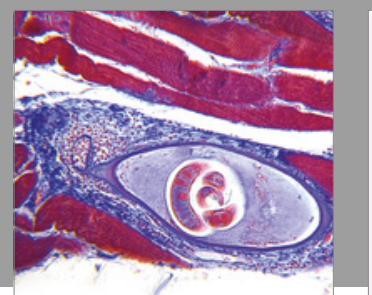

Gastroenterology Research and Practice
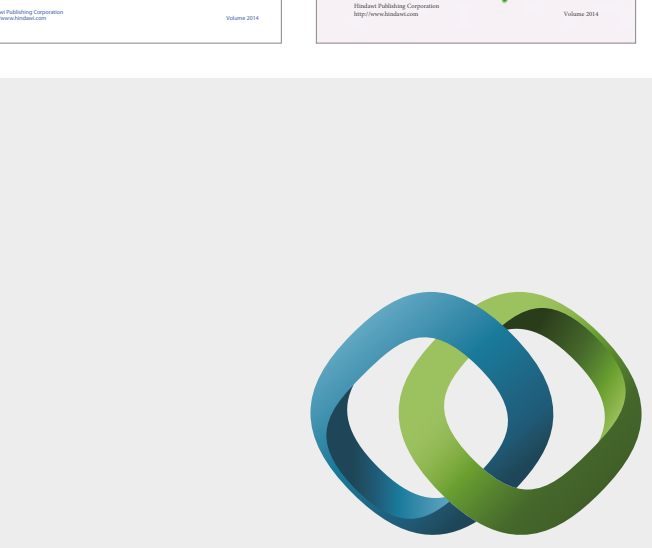

\section{Hindawi}

Submit your manuscripts at

https://www.hindawi.com
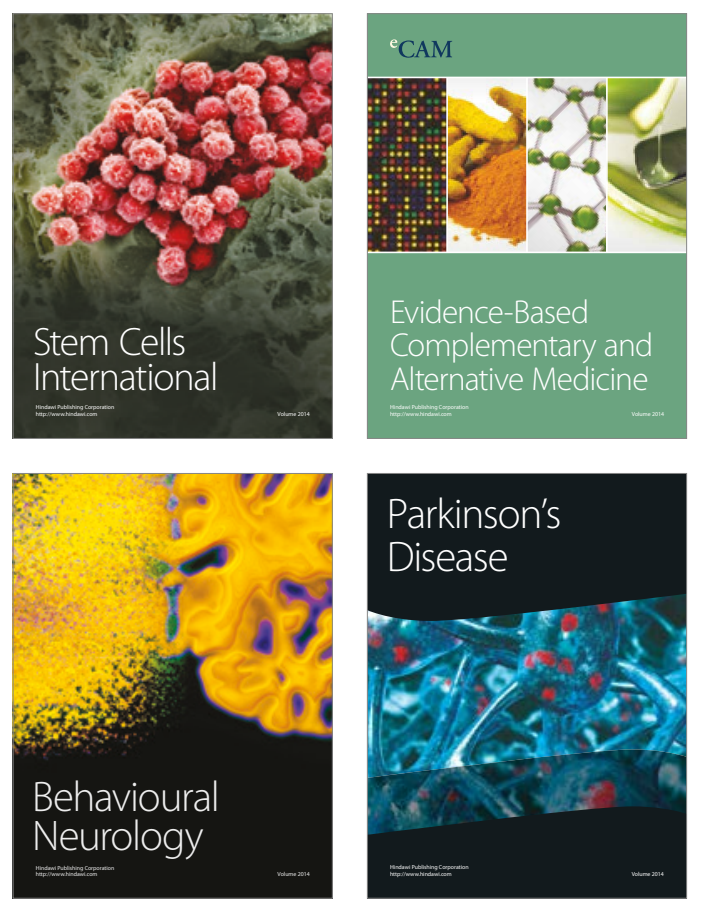
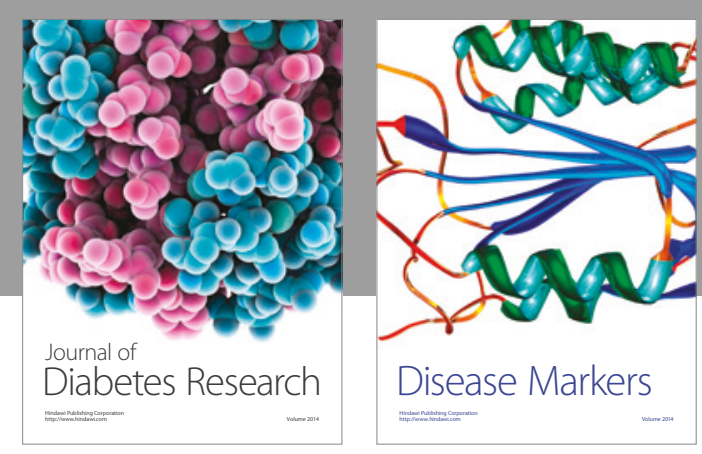

Disease Markers
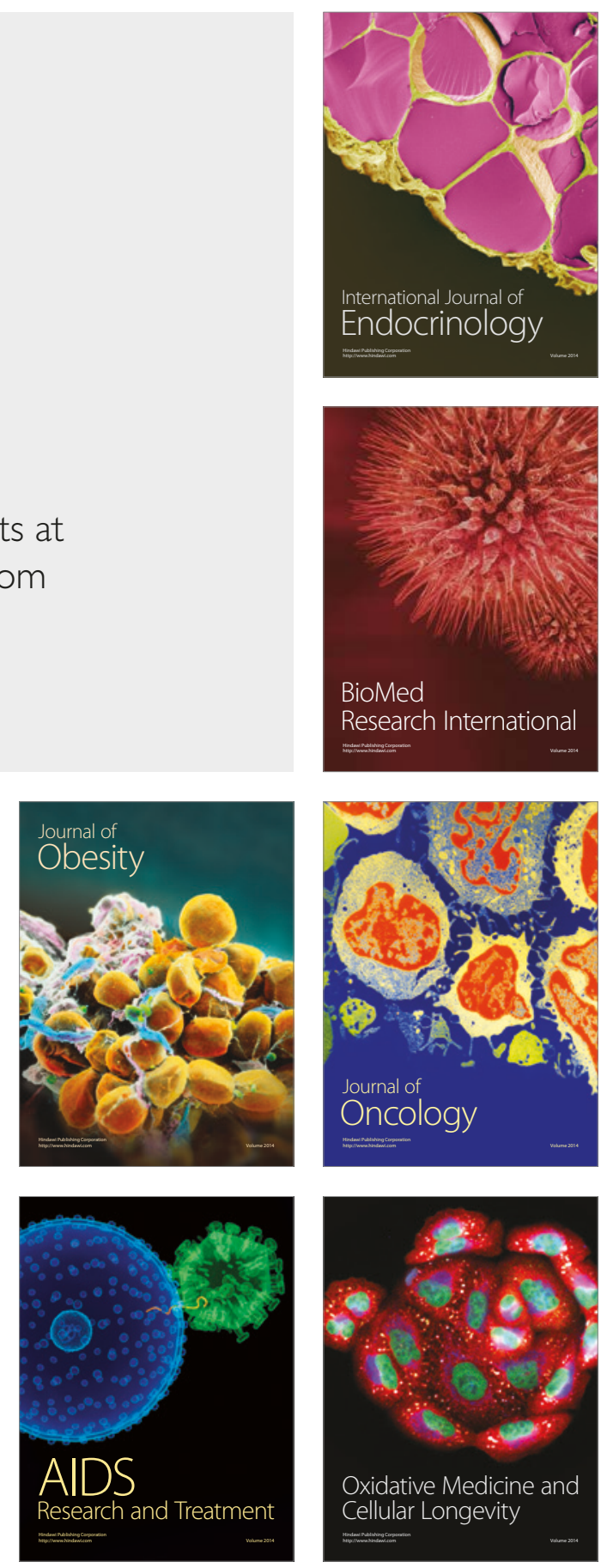